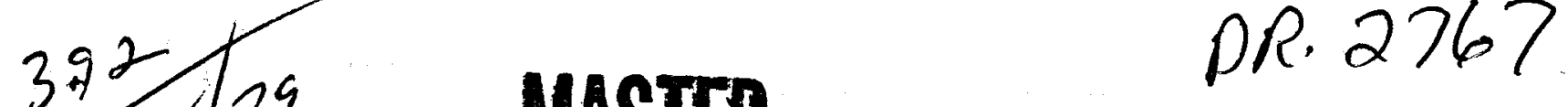

\title{
MASTER
}

IDO-10081

Programs

$\div \quad$ Idaho

Operations

Office

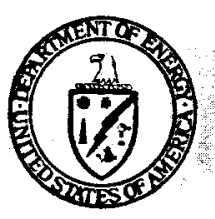

\section{COMPLETION REPORT: \\ RAFT RIVER \\ GEOTHERMAL PRODUCTION \\ WELL FOUR \\ (RRGP-4)}

L.G. MILLER

EG\&G IDAHO, INC.

and

S.M. PRESTWICH

DOE-ID

February 1979

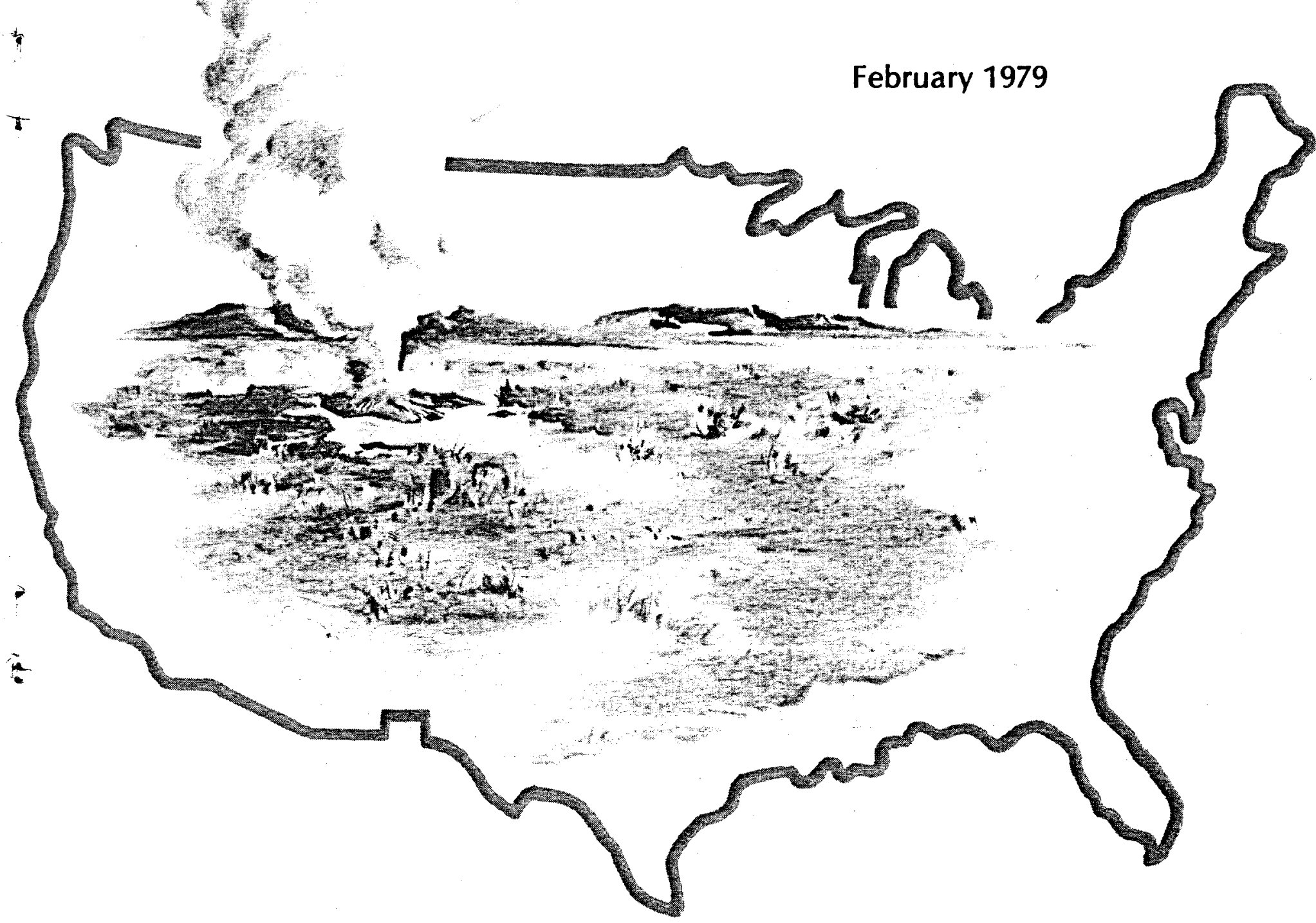

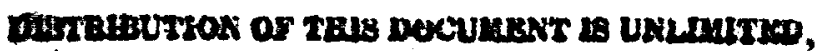




\section{DISCLAIMER}

This report was prepared as an account of work sponsored by an agency of the United States Government. Neither the United States Government nor any agency Thereof, nor any of their employees, makes any warranty, express or implied, or assumes any legal liability or responsibility for the accuracy, completeness, or usefulness of any information, apparatus, product, or process disclosed, or represents that its use would not infringe privately owned rights. Reference herein to any specific commercial product, process, or service by trade name, trademark, manufacturer, or otherwise does not necessarily constitute or imply its endorsement, recommendation, or favoring by the United States Government or any agency thereof. The views and opinions of authors expressed herein do not necessarily state or reflect those of the United States Government or any agency thereof. 


\section{DISCLAIMER}

Portions of this document may be illegible in electronic image products. Images are produced from the best available original document. 
Printed in the United States of America Available from

National Technical Information Service U.S. Department of Commerce 5285 Port Royal Road Springfield, Virginia 22161

Price: Printed Copy $\$ 4.50$; Microfiche $\$ 3.00$

\section{NOTICE}

This report was prepared as an account of work sponsored by the United States Government. Neither the United States nor the Department of Energy, nor any of their employees, nor any of their contractors, subcontractors, or their employees, makes any warranty, express or implied, or assumes any legal liability or responsibility for the accuracy, completeness or usefulness of any information, apparatus, product or process disclosed, or represents that its use would not infringe privately owned rights. 
COMPLETION REPORT:

RAFT RIVER

GEOTHERMAL PRODUCTION WELL FOUR

(RRGP-4)

APPROVED:

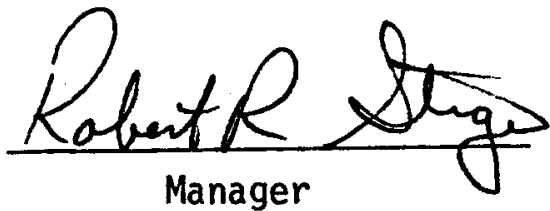

Geothermal Technical Development

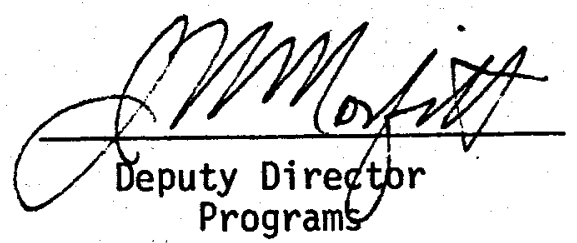

NOTICE

This eport was prepared as an account of work

sponzored by the United States Govemment. Neither the

United States nor the United States Department of

Energy, nor any of their employees, nor eny of their

contrnctors, subcontracton, or thetr employees, makes

any warranty, expres or implied, of assumes any leal

libbility or nesponstbility for the accuracy, completenes

or usefulness of any information, appantus, product or

process dieclosed, or represents that it uns product or

process diuclosed, of represents that ith we would not
infringe privately owned rights. 
COMPLETION REPORT:

RAFT RIVER

GEOTHERMAL PRODUCTION WELL FOUR

(RRGP-4)

L. G. Miller

EG\&G Idaho, Inc.

and

S. M. Prestwich

DOE-ID

February 1979

U.S. Department of Energy

Idaho Operations Office

550 Second Street.

Idaho Falls, Idaho 83401 


\section{ABSTRACT}

The fourth Raft River well was originally drilled to $866 \mathrm{~m}(2840 \mathrm{ft})$, for use as a test injection we11. This well allowed the injection of geothermal fluids into the intermediate zone--above the geothermal production zone and below the shallow groundwater aquifers.

After this testing, the well was deepened and cased for use as a production well. The well's designation was changed from RRGI-4 to RRGP-4. This report describes the drilling and completion of both drilling projects. Results of well tests are also included. 
CONTENTS

ABSTRACT ........................ . . . i i

I. INTRODUCTION .......................... 1

II. DRILLING SUMMARY . . . . . . . . . . . . . . . 1

1. RRGI-4 DRILLING . . . . . . . . . . . . . . 1

2. RRGP-4 DEEPENING ................. 5

III. SURFACE AND CONTAINMENT EQUTPMENT AND SERVICES . . • . . • • 8

1. CONTAINMENT EQUIPMENT - SURFACE HOLE . . . . . . . . . 8

2. CONTAINMENT EQUIPMENT - PRODUCTION HOLE . . . . . . . 8

3. CEllar ........................ 11

4. DRILLING RECORDER ................... . . 11

5. WELLHEAD ..................... 11

IV. DOWNHOLE EQUIPMENT AND SERVICES . . . . . . . . . . . . 11

1. SURFACE CASING .................... 11

2. INTERMEDIATE CASING ................. 11

3. PRODUCTION CASING . . . . . . . . . . . . . . 11

4. DRILL BIT SUMMARY ................. 12

5. CORING ..................... 12

6. DRILLING FLUID . . . . . . . . . . . . . 13

7. SAMPLE LOGGING. . . . . . . . . . . . . 13

8. FORMATION TOPS ............................... 13

9. LOGGING . . . . . . . . . . . . . . 14

10. CEMENTING . . . . . . . . . . . . . . 17

11. LINER HANGER . . . . . . . . . . . . . . 17

12. DRILLING PROBLEMS ................... 18 
v. INJECTION TEST .................................. 19

APPENDIX A DAILY DRILLING REPORTS .............. . . . A-1

APPENDIX B BIT RECORD ....................... B-

APPENDIX C DIRECTIONAL DRILLING SURVEY SUMMARY $\ldots \ldots \ldots$

APPENDIX D CASING RECORD ............... D-

\section{FIGURES}

1. Raft River geothermal site and location of wells ...... 2

2. Location survey ................ 3

3. Temperature logs ................... 6

4. Drilling and operations survey ........... 7

5. Subsurface well status ............... 9

6. Containment equipment ............... 10

7. Injection pump test .................. 20

C-1 Directional drilling survey summary .............. C-5

\section{TABLES}

I. Log Record, 0 to 580 meters (0 to 1900 feet) . . . . . . 14

II. Log Record, 550 to 1065 meters (1800 to 3500 feet) . . . . 15

III. Log Record, Leg A, 1020 to 1650 meters (3350 to 5420 feet) . . 15

IV. Log Record, Leg B, 1020 to 1560 meters (3350 to 5115 feet) . 16

A-I. Daily Drilling Reports, RRGI-4 ................ A-I

A-II. Daily Drilling Reports, RRGP-4 ............ A-7

B-I. Bit Record, RRGI-4 ............ . . B-2

B-II. Bit Record, RRGP-4 . . . . . . . . . . B-3

C-I. Directional Drilling Survey Summary, RRGP-4A ....... C-2 
Page

C-II. Directional Drilling Survey Summary, RRGP-4B . . . . . . C-4

D-I. Intermediate Casing Summary .......... D-2

D-II. Production Casing Sumary ............ D-3 


\author{
COMPLETION REPORT: \\ RAFT RIVER \\ GEOTHERMAL PRODUCTION WELL FOUR \\ (RRGP-4)
}

\title{
I. INTRODUCTION
}

This report describes the drilling of Raft River Geothermal Injection Well Four (RRGI-4), as well as the eventual modification of the well for use as a production well (RRGP-4). Previous Raft River wells established the feasibility of using the valley's geothermal resource for a 5-MW power plant and for various nonelectric applications. RRGI-4 was used as an experimental injection well, to test the injection of spent fluids into the intermediate-depth aquifer. The well was later deepened with multiple legs and converted into a production well, RRGP-4.

RRGI-4 was sited near RRGE-1, to test the effects of intermediate injection on the production zone while providing an optimum location for later conversion to production status (see Figure 1 and 2). Drilling began Apri1 18, 1977, and RRGI-4 was completed on May 4, 1977, to a depth of $866 \mathrm{~m} \mathrm{GL}[\mathrm{a}]$ ( $2840 \mathrm{ft}$ referenced to ground level). RRGP-4 drilling began on September 21, 1978, and was completed on November 15, 1978. Two legs were drilled to depths of $1652 \mathrm{~m} \mathrm{GL}(5420 \mathrm{ft})$ and $1558 \mathrm{~m} \mathrm{GL}(5110 \mathrm{ft})$.

\section{DRILLING SUMMARY}

\section{RRGI-4 DRILLING}

The fourth Raft River geothermal well, RRGI-4, was designed for injection into the intermediate-zone aquifer. This zone was selected in order to minimize contamination of the groundwater and production aquifers, and to reduce well cost. The location was approximately $1 \mathrm{~km}(1 / 2 \mathrm{mi})$ south of RRGE-1. The land was available, the hydrogeology was well understood, and hydrogeologists suspected major upward leakage from the production zone. This would allow them to monitor and understand the interconnections of leaky reservoirs by al ternately producing and monitoring RRGE- 1 and RRGI-4. Researchers hoped injection testing would create a man-made hydro-cap, stopping the upward leakage of the geothermal production zone and thereby retarding the reservoir pressure loss incurred during full-scale field production. In addition, the reduction of well cost and injection-pump requirements was significant when compared to deep injection into the production zone.

[a] All depths are referenced from the Kelly Bushing, $4.3 \mathrm{~m}$ (14 ft) above ground level, unless otherwise noted (as in this case). 


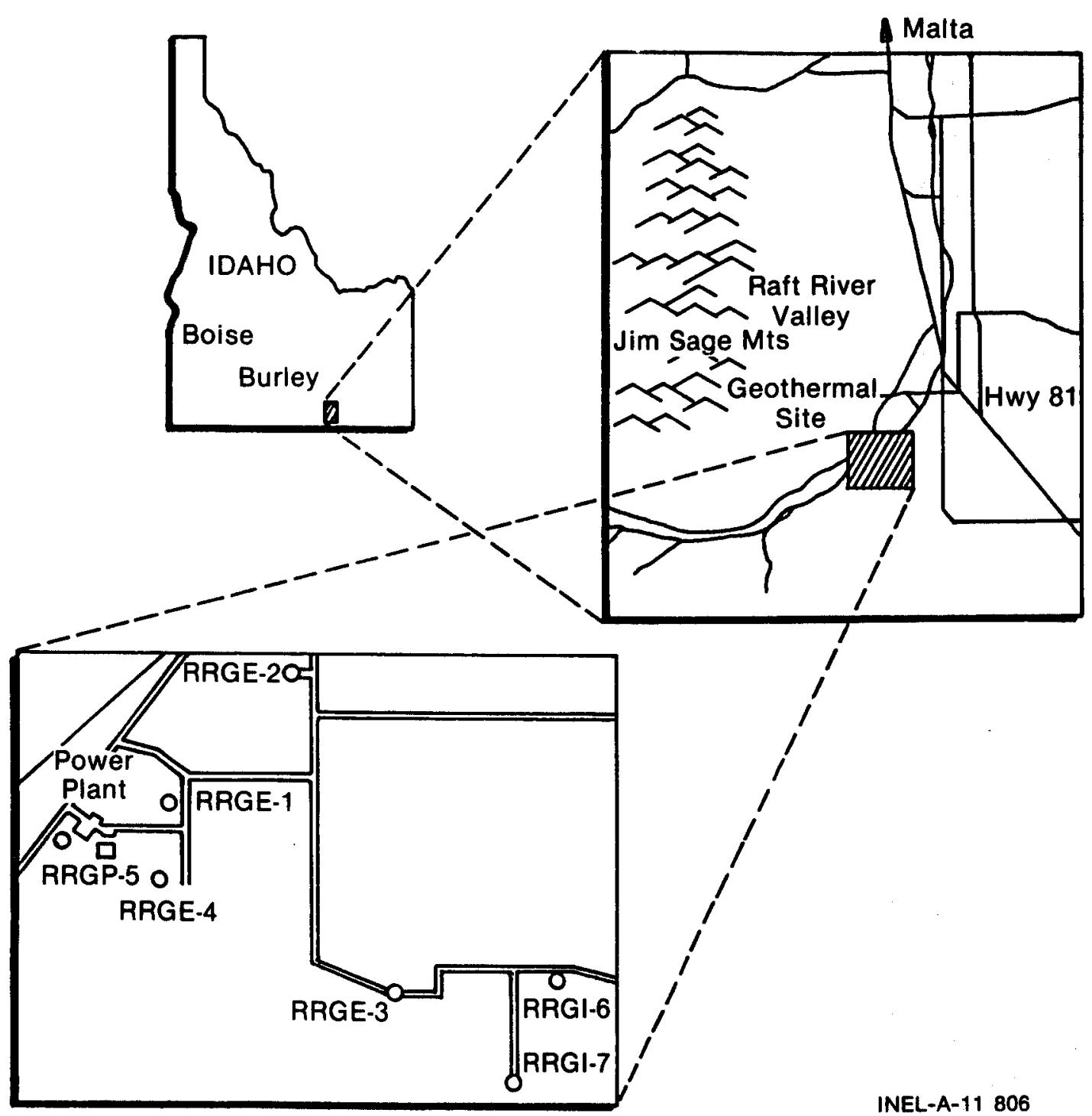

Fig. 1 Raft River geothermal site and location of wells. 


\section{Section 23}

T-15-S

R-26-E

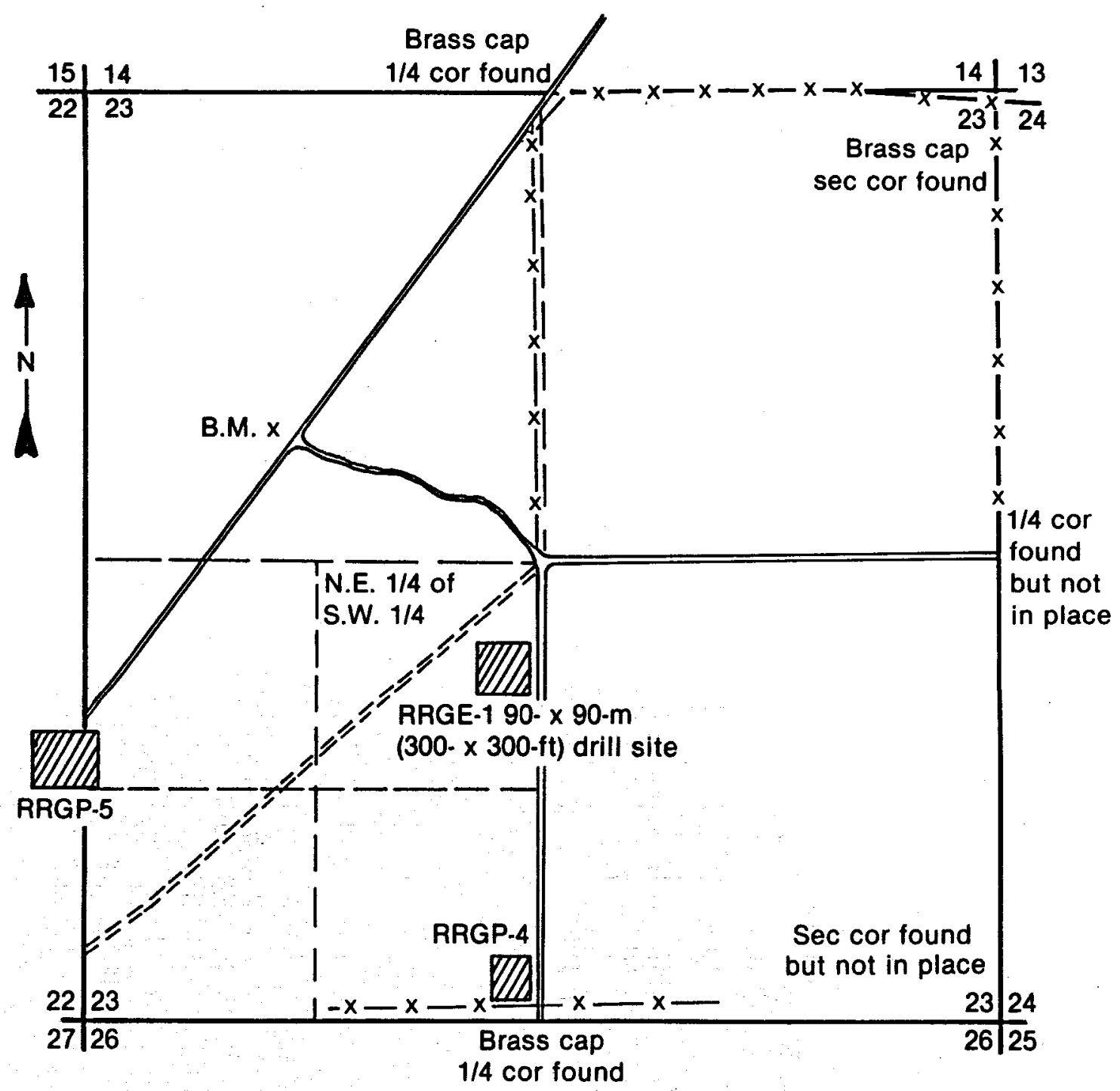

Scale: $1 \mathrm{~cm}=120 \mathrm{~m}(1 \mathrm{in} .=1,000 \mathrm{ft}) \quad$ INEL-A-11 807

Fig. 2 Location survey. 
The drill site, with approximate dimensions of $76 \times 76 \mathrm{~m}(250 \times 250 \mathrm{ft})$, was completed prior to rig move-on. The site preparation included excavation of a fluid reserve pit; leveling, grading, and graveling of the site; and road construction. A temporary water line from RRGE-1 to the site provided drilling water.

A dry-hole digger drilled a $91-\mathrm{cm}$ (36-in.) diameter hole and set $12 \mathrm{~m}$ $(40 \mathrm{ft})$ of $76-\mathrm{cm}(30-\mathrm{in}$.$) diameter conductor pipe. This contractor$ cemented the pipe with plant-mix concrete. The dry-hole digger also drilled the rat and mouse holes. A sub-contractor constructed a 2.4$\times 2.4-\times 3-\mathrm{m}(8-\times 8-\times 10-\mathrm{ft})$ concrete-lined cellar around the conductor pipe.

Procurement was completed by the end of March, and drilling began on April 8, 1977. Colorado Well Service, of Rangely, Colorado, was awarded the drilling contracts. The rig, Rig 99, was a truck-mounted Cabot 900 with a 4-m (14-ft) substructure and a hoist capacity of $136,000 \mathrm{~kg}$ $(300,000 \mathrm{lb})$.

The surface hole was drilled with a $38-\mathrm{m}$ (15-in.) bit and reamed to $66 \mathrm{~cm}$ (26 in.). On April 10, 1977, $122 \mathrm{~m}(400 \mathrm{ft})$ of $51-\mathrm{cm}(20-\mathrm{in.}), \mathrm{K}-55$, $140-\mathrm{kg} / \mathrm{m}(94-1 \mathrm{~b} / \mathrm{ft})$ surface casing were set.

A 31-cm (12-1/4-in.) hole was drilled to $582 \mathrm{~m}$ (1909 ft). It was reamed to $44 \mathrm{~cm}(17-1 / 2$ in.) after logging and coring the hole. Drillers attempted to core at a depth of $577 \mathrm{~m}(1894 \mathrm{ft})$, using the Joides quadracone core-bit system on loan from LASL. During the trip into the hole with the corebarrel, the $30-\mathrm{cm}(12-i n$.$) OD corebarrel stabilizer$ became stuck at $438 \mathrm{~m}(1436 \mathrm{ft})$. Backoff shot service was used to disengage the drill pipe from the coring assembly. The fish was recovered by using jars and bumper sub to free the stabilizer. Dresser-Atlas and the U.S. Geological Survey ran logs of the hole. Coring was again attempted, recovering $1 \mathrm{~m}$ (42 in.) of core.

At a depth of $580 \mathrm{~m}(1901 \mathrm{ft}), 34-\mathrm{cm}(13-3 / 8-\mathrm{in}),. K-55,81-\mathrm{kg} / \mathrm{m}$ $(54.5-1 \mathrm{~b} / \mathrm{ft})$ casing was run and stage-cemented. The shoe was drilled out with a 31-cm $(12-1 / 4-i n$.$) bit and drilling proceeded to a depth of$ $643 \mathrm{~m}(2110 \mathrm{ft})$. At this depth it was necessary to trip out for a new bit. A prior decision had been made to cut a core at selected intervals which coincided with trips for new bits. During the trip in with the corebarrel, however, an obstruction was encountered at $575 \mathrm{~m}(1887 \mathrm{ft})$. Milling tools were used, but they only sidetracked around the fish. Logging determined the fish to be the $34-\mathrm{cm}(13-3 / 8-i n$.$) casing shoe,$ 
float collar, and two joints of casing, which had parted and fallen $20 \mathrm{~m}(67 \mathrm{ft})$. A fishing-spear attempt was made to jar the fish loose and let it fall downhole, hopefully creating a more vertical entry through the casing. The fish could not be moved. Three attempts to pass the bit and string through the parted casing were successful, enabling drilling to proceed to a depth of $860 \mathrm{~m}(2820 \mathrm{ft})$. A second core was cut from 860 to $866 \mathrm{~m}$ (2820 to $2840 \mathrm{ft})$.

Predrilling parameters 1 imited total depth to either $1060 \mathrm{~m}(3500 \mathrm{ft})$ or the depth at which bottom-hole temperature would reach $121^{\circ} \mathrm{C}\left(250^{\circ} \mathrm{F}\right)$. Temperature logs taken during this period showed temperatures of $114^{\circ} \mathrm{C}$ $\left(237^{\circ} \mathrm{F}\right)$ at the top of the parted casing, and $122^{\circ} \mathrm{C}\left(252^{\circ} \mathrm{F}\right)$ at $823 \mathrm{~m}$ $(2700 \mathrm{ft})$. Logs are shown in Figure 3. Artesian flow had reached about $18 \mathrm{~L} / \mathrm{sec}(300 \mathrm{gpm})$. The decision was made to terminate drilling.

Prior to releasing the rig, four joints of $24-\mathrm{cm}(9-5 / 8-\mathrm{in}$.$) casing$ were passed through the parted $34-\mathrm{cm}(13-3 / 8-i n$.$) casing to verify$ that the well could be deepened and completed as a production well at a later date. Short injection tests were run to verify predicted injection capacities of the well.

\section{RRGP-4 DEEPENING}

On September 21, 1978, the well was reentered and the second phase of drilling was begun. The project is summarized in Figure 4 . Since the two bottom joints of casing could not be dislodged earlier, the decision was made to drill around them. Only minor problems were encountered getting around the casing, since the bit usually veered to the side.

Casing was run and cemented from $1954 \mathrm{~m}(3457 \mathrm{ft})$ up to the $24-\mathrm{cm}$ (9-5/8-in.) casing hanger at $461 \mathrm{~m}(1512 \mathrm{ft})$. A cement bond $10 \mathrm{~g}$ (CBL) indicated little or no bonding from $560 \mathrm{~m}$ (1837 ft) up to casing hanger. Two hundred sacks of cement were mixed and squeezed down through the fluted-casing hanger. A second CBL indicated no bond from 558 to $523 \mathrm{~m}$ ( 1830 to $1715 \mathrm{ft}$ ) and $20 \%$ bond from 523 to $461 \mathrm{~m}$ (1715 to $1512 \mathrm{ft}$ ). Cement was drilled out to above the shoe and the BOP-casing system was pressure-tested to $1.2 \times 10^{6} \mathrm{~kg} / \mathrm{m}^{2}(1700 \mathrm{psi})$ with the Halliburton pumper truck. The shoe was then drilled through to $1082 \mathrm{~m}(3550 \mathrm{ft})$ in preparation for whipstocking. Using a turbodrill, the hole was drilled to $1098 \mathrm{~m}(3602 \mathrm{ft})$. The hole gained angle--up to 10.5 degrees in the N5W direction at a depth of $1175 \mathrm{~m}(3853 \mathrm{ft})$. The hole seemed tight in several locations, so the hole was reamed to the bottom. 


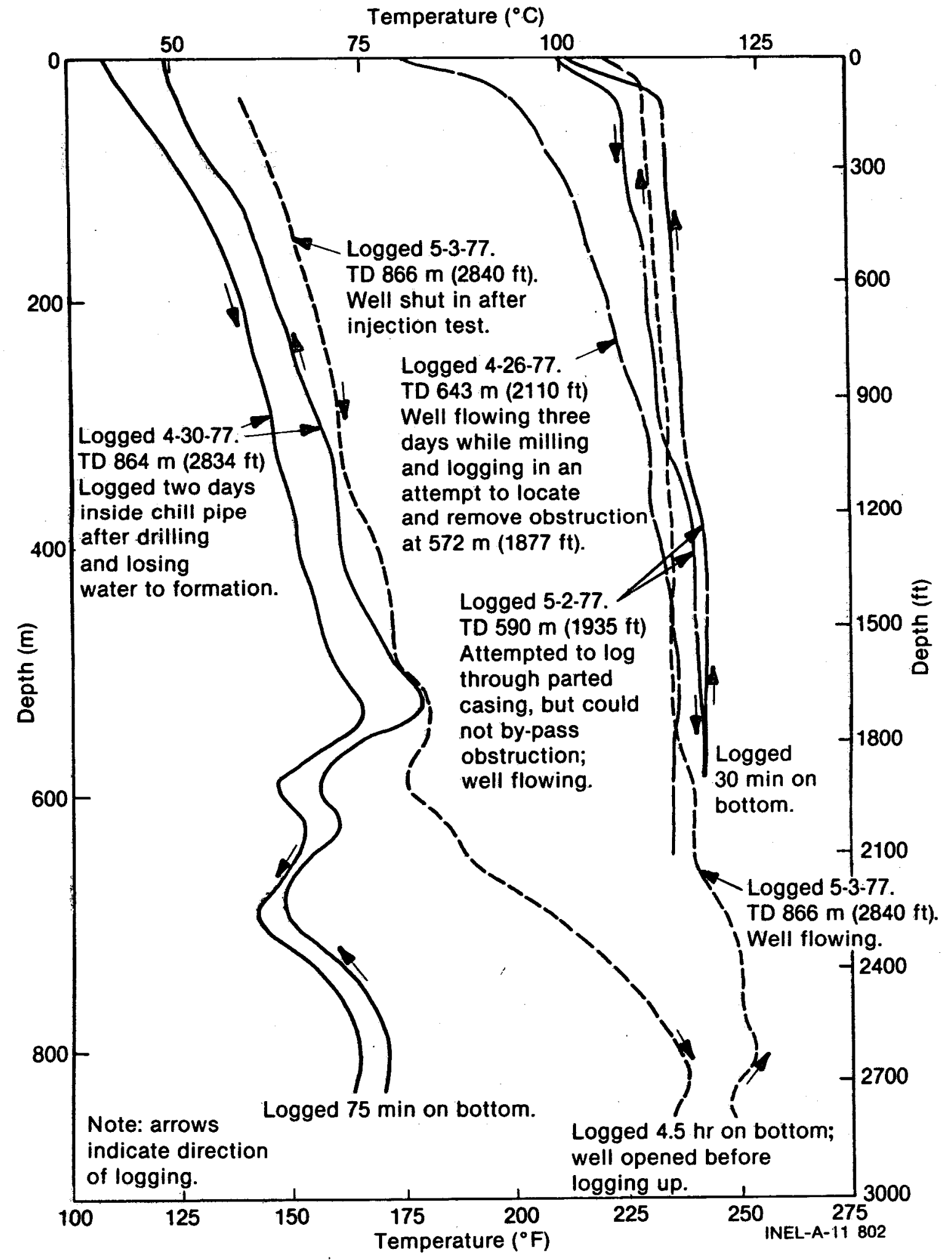

Fig. 3 Temperature logs. 


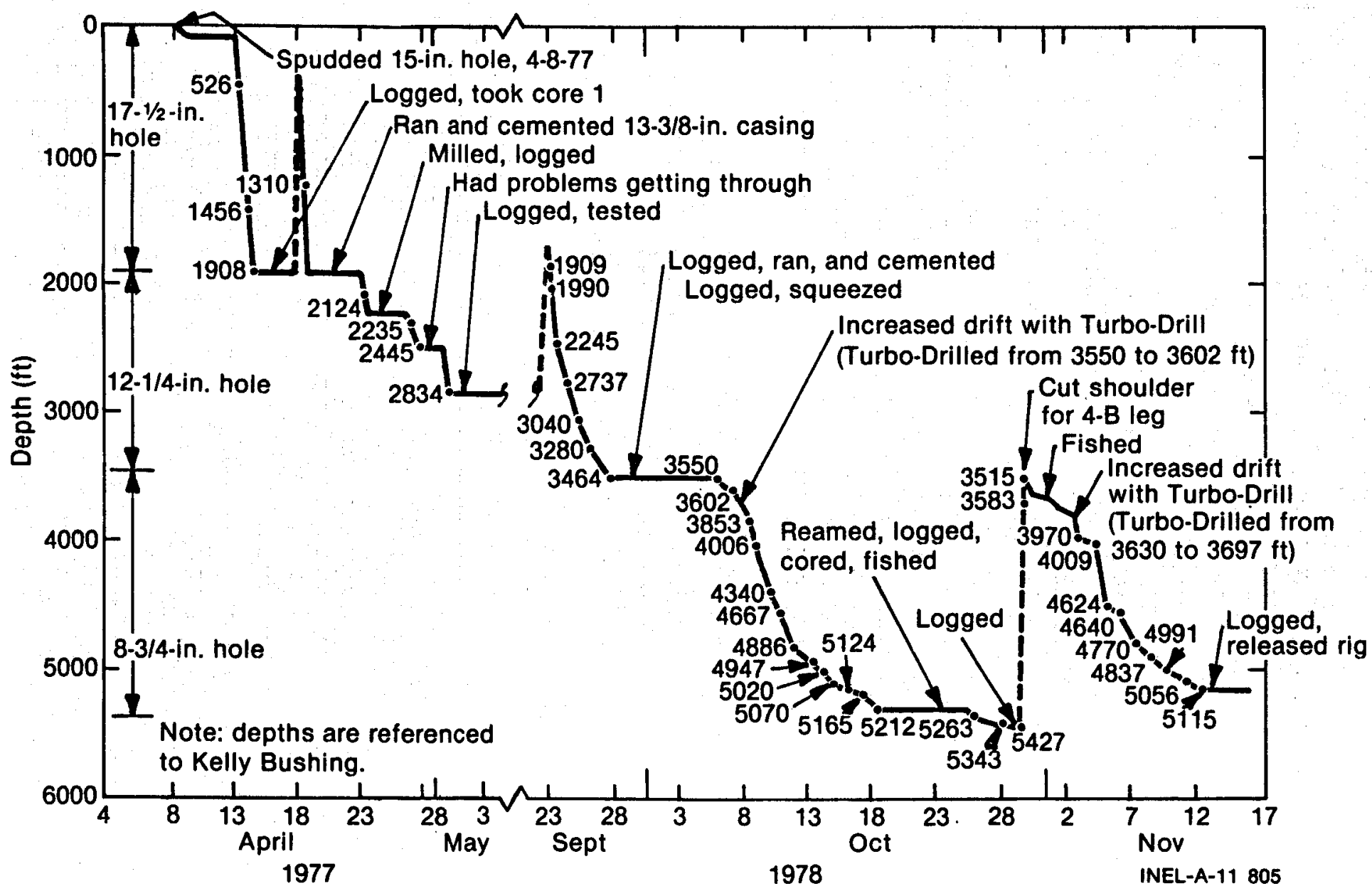

Fig. 4 Drilling and operations summary. 
During the drilling and surveying to $1589 \mathrm{~m}$ (5212 ft), a key seat formed. The hole was reamed from 1128 to $1167 \mathrm{~m}(3700$ to $3830 \mathrm{ft})$. A1so, the last $2 \mathrm{~m}$ ( $5 \mathrm{ft}$ ) of the hole were tight and caused some sticking problems. The hole was logged, but the logger lost an acoustic tool in the well. Several fishing runs were made before most of the tool was recovered. The remainder of the tool was milled, and two magnet runs recovered the junk. The hole was drilled on to $1654 \mathrm{~m}(5427 \mathrm{ft})$ and logged.

During the drilling of a shoulder for the second leg, the Monel drill collar broke. On the second fishing run, the fish was recovered. The turbodrill was used to drill from 1106 to $1222 \mathrm{~m}$ (3630 to $4009 \mathrm{ft}$ ). The turbodrill was then layed down, and a 22-cm (8-3/4-in.) bit was picked up for further drilling to $1414 \mathrm{~m}(4640 \mathrm{ft})$. A 5-m (15-ft) core was cut at $1414 \mathrm{~m}$ (4640 $\mathrm{ft})$, recovering $3 \mathrm{~m}(9 \mathrm{ft})$ of core. A second $5 \mathrm{~m}(15 \mathrm{ft})$ of core were cut at the interface of the Tertiary-Precambrian, recovering $2 \mathrm{~m}(7 \mathrm{ft})$.

The hole was then drilled to $1559 \mathrm{~m}(5115 \mathrm{ft})$ and cleaned for logging. After logging, an attempt was made to get back in leg $A$ using the turbodrili, Monel drill collar, and a 2-degree kick sub. The attempt failed and the rig was released. Figure 5 illustrates the current status of RRGP-4.

\section{SURFACE AND CONTAINMENT EQUIPMENT AND SERVICES}

\section{CONTAINMENT EQUIPMENT - SURFACE HOLE}

A $51-\mathrm{cm}$ (20 in.) single-gate Shaffer blowout preventer was set between the $51-\times 30-\mathrm{cm}(20-\times 12-i n$.$) expansion spool and drilling nipple, for drilling$ the 44-cm $(17-1 / 2-$ in.) hole to $582 \mathrm{~m}$ (1909 ft).

2. CONTAINMENT EQUIPMENT - PRODUCTION HOLE

After setting the 34-cm (13-3/8-in.) casing at $579 \mathrm{~m}$ (1901 $\mathrm{ft}$ ), the following containment stack (1 isted from expansion spool up) was used (sée figure 6).

(1) WKM 51- x 30-cm (20- x 12-in.) expansion spool

(2) WKM 30-cm (12-in.) master valve

(3) Adaptor spool

(4) Shaffer double-gate 30-cm (12-in.) BOP

(5) Hydril Type-GK 30-cm (12-in.) BOP

(6) Grant $30-\mathrm{cm}$ (12-in.) rotating head. 


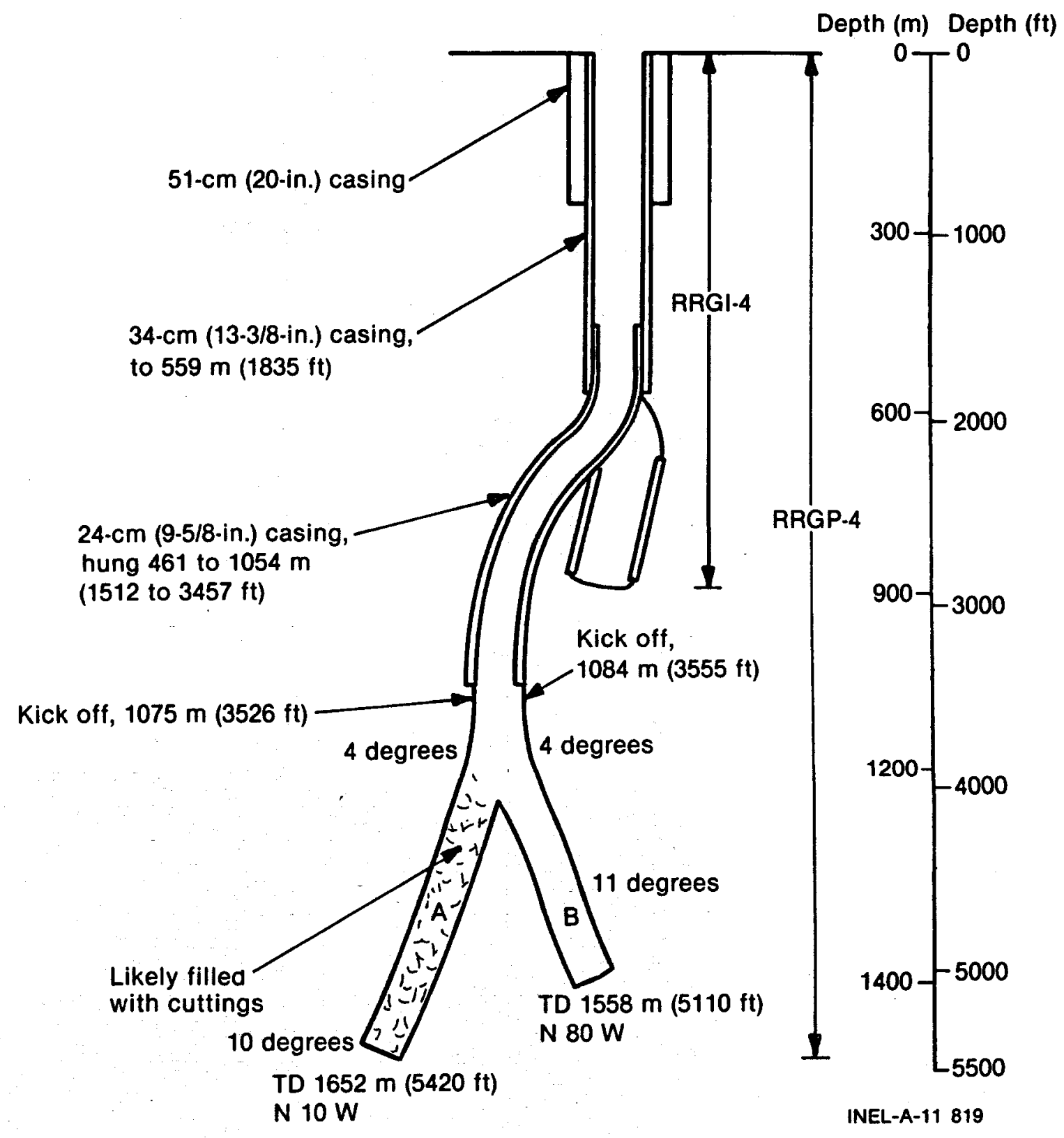

Fig. 5 Subsurface well status. 


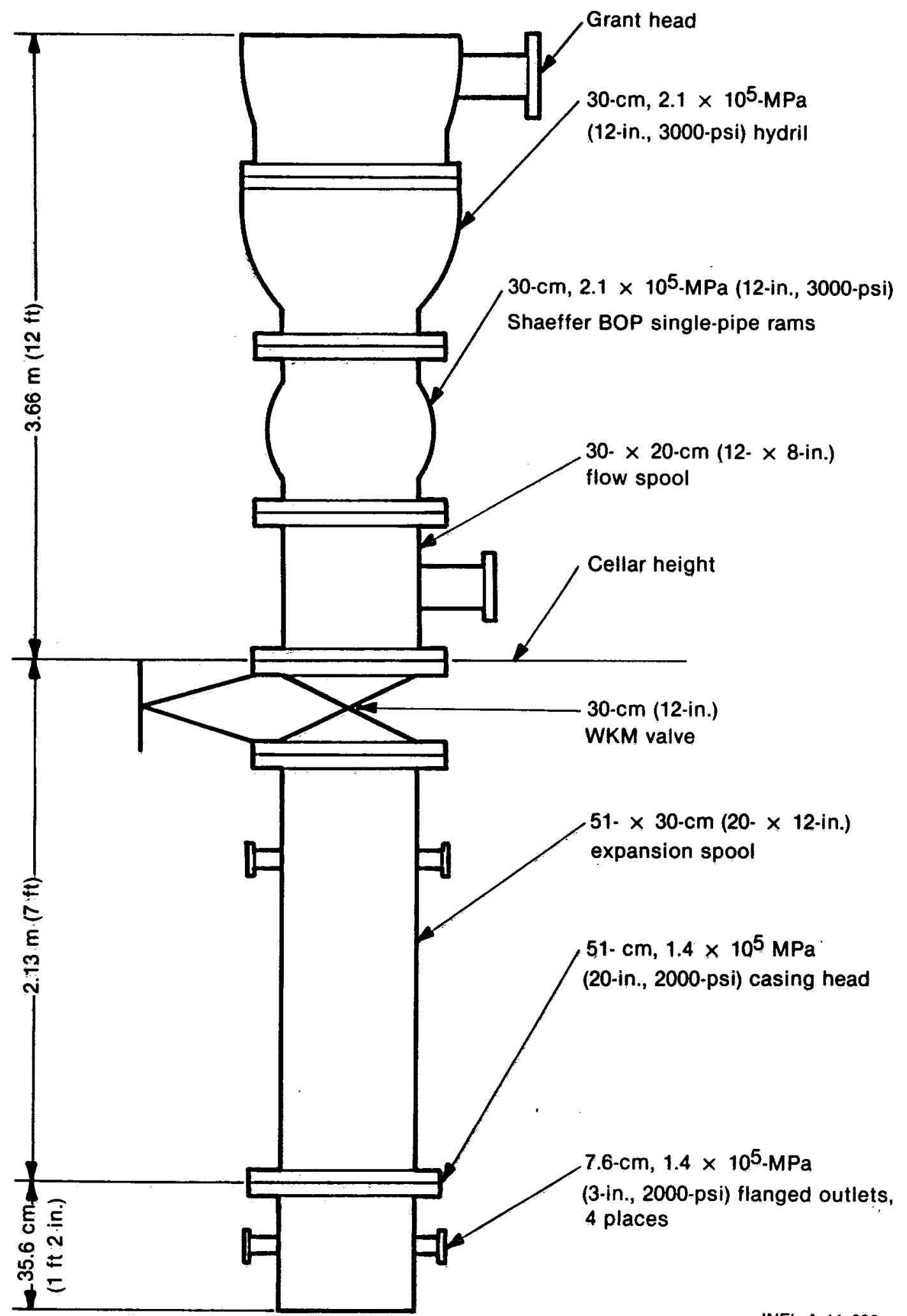

INEL-A-11 808

Fig. 6 Containment equipment. 


\section{CELLAR}

A 2.4- $\times 3.0-\times 2.4-m(8-\times 10-\times 8-f t)$ reinforced-concrete cellar was built to accomodate the BOP stack.

4. DRILLING RECORDER

A geolograph drilling recorder was used during drilling to record depth, penetration rate, bit weight, and pump pressure.

\section{WELLHEAD}

The permanent wellhead on this well consists of a standard WKM wellhead system. The casing head, with its $51-\mathrm{cm}\left(20-\mathrm{in}\right.$.) $141-\mathrm{kg} / \mathrm{cm}^{2}$ (2000-psi) API flange, is welded directly to the $51-\mathrm{cm}(20-\mathrm{in}$.) well casing. The expansion spool mates to the $51-\mathrm{cm}(20-\mathrm{in}),. 141-\mathrm{kg} / \mathrm{cm}^{2}(2000-\mathrm{psi})$ API casing head flange on the bottom and the $30-\mathrm{cm}(12-\mathrm{in}),. 28-\mathrm{kg} / \mathrm{cm}^{2}(400-\mathrm{psi})$ ANSI flanged master gate valve on the top. Both sides of the expansion spool contain 7.5-cm (3-in.) valved outlets with $7.5-\mathrm{cm}(3-\mathrm{in}),. 141-\mathrm{kg} / \mathrm{cm}^{2}$ (2000-psi) API flanges.

A hanger spool mates with the master valve on the bottom, and with a $20-\mathrm{cm}(8-i n$.$) ,$ $42-\mathrm{kg} / \mathrm{cm}^{2}(600-\mathrm{psi})$ ANSI flanged power-seal gate valve on top. Above the powerseal gate valve is a $20-\mathrm{cm}(8-\mathrm{in}),. 42-\mathrm{kg} / \mathrm{cm}^{2}(600-\mathrm{psi})$ ANSI tee (or cross). Expansion can be measured by monitoring the location of a 7-microcurie encapsulated cobalt -60 radioactive source embedded in the top edge of the $34-\mathrm{cm}$ (13-3/8in.) casing.

\section{DOWNHOLE EQUIPMENT AND SERVICES}

\section{SURFACE CASING}

Ten joints of $51-\mathrm{cm}(20-\mathrm{in}$.$) H-40 casing were tack-welded at each joint, and set$ and cemented at $122 \mathrm{~m}(400 \mathrm{ft})$. Parrish 011 Tool ran the casing.

\section{INTERMEDIATE CASING}

Forty-nine joints of $34-\mathrm{cm}(13-3 / 8-\mathrm{in}),. 81-\mathrm{kg} / \mathrm{m}(54.5-1 \mathrm{~b} / \mathrm{ft}), \mathrm{K}-55$, range-3 casing, guide shoe, float collar, and DV tool were run by Lamb "JAM" (Joint Analyzed Make-Up) system. The second joint up from the guide shoe did not make up we11. It showed torquing of $18,440 \mathrm{~N}^{\circ} \mathrm{m}(13,600 \mathrm{ft}-1 \mathrm{~b})$. The average jo int torque was $9220 \mathrm{~N} \cdot \mathrm{m}(6800 \mathrm{ft}-1 \mathrm{~b})$. The $18,440-\mathrm{N}^{\circ} \mathrm{m}(13,600-\mathrm{ft}-1 \mathrm{~b})$ torque could have resulted from the threaded ends butting against each other.

\section{PRODUCTION CASING}

Forty-eight joints of 24-cm (9-5/8-in.) casing were run and cemented from the casing hanger from 461 to $1054 \mathrm{~m}$ (1512 to $3457 \mathrm{ft}$ ). The casing was Type $\mathrm{K}-55,54 \mathrm{~kg} / \mathrm{m}$ (36 $\mathrm{lb} / \mathrm{ft}) \mathrm{BT} \& \mathrm{C}$, Range 3 . 


\section{DRILL BIT SUMMARY}

A 38-cm (15-in.) hole was drilled to $124 \mathrm{~m}$ (407 ft). with a Security S3J bit, then reamed to $66 \mathrm{~cm}$ (26 in.) with a Smith hole opener. A 31-cm (12-1/4-in.) hole was drilled from 122 to $579 \mathrm{~m}$ (400 to $1901 \mathrm{ft}$ ) with Smith nonsealed bearing bits. The hole was then reamed with a $44-\mathrm{cm}$ (17-1/2-in.) hole opener. A 31-cm (12-1/4-in.) hole was drilled to $866 \mathrm{~m}(2840 \mathrm{ft})$ with water, and completed open hole.

When the rig moved back over the hole to complete it as a production well, the hole was deepened to $1056 \mathrm{~m}(3464 \mathrm{ft})$ with four Smith Type-SVH, $31-\mathrm{cm}\left(12-1 / 4-i n_{.}\right)$bits and one Hughes Type-OWVJ, 31-cm $(12-1 / 4-i n$.$) bit.$

After cementing, a Hughes 22-cm (8-3/4-in.) Type-JD8 bit was used to drill the cement, the shoe, and the formation to $1075 \mathrm{~m}(3526 \mathrm{ft}$ )--the kickoff point for sidetracking. Two Reed 22-cm (8-3/4-in.) Type-F31GJ bits were used on the turbodrill to sidetrack $100 \mathrm{~m}(327 \mathrm{ft})$ of hole.

Nine bits were used to drill from $1174 \mathrm{~m}(3853 \mathrm{ft})$ to $1654 \mathrm{~m}(5427 \mathrm{ft})$. These included one Reed Type-F34J, three Security Type-M84F, two Security Type-H-100F, and three Hughes J-77 bits. One of the Hughes $\mathrm{J}-77$ bits was a rerun bit.

A Hughes XDV and a rerun Reed bit were used to build a shoulder for Leg $B$. During the sidetracking, a Reed 22-cm (8-3/4-in.) Type F34J drilled $12 \mathrm{~m}$ $(41 \mathrm{ft})$. Another Reed Type F31G was used to ream the shoulder and new hole, and a third Reed Type F3IG was used with the turbodrill to sidetrack an additional $95 \mathrm{~m}$ (312 ft).

After drilling $192 \mathrm{~m}(631 \mathrm{ft})$ with a Security S-88, two cores were taken using two Hycalog 20-cm (7-7/8-in.) bits each coring $5 \mathrm{~m}(15 \mathrm{ft})$. Two Hughes Type J-77 and two Security Type H-100F were used to complete the second leg to $1559 \mathrm{~m}(5115 \mathrm{ft})$.

\section{CORING}

Two cores were recovered from the upper part of the (RRGI-4) hole using a Joides $20-\mathrm{cm}$ (8-in.) OD $\times 9-\mathrm{m}(30-\mathrm{ft})$ long corebarre1. The Joides system components were loaned to the INEL by Los Alamos Scientific Laboratory (LASL) and Scripp Oceanographic Laboratory'. The system is comprised of a 20-cm (8-in.) marine corebarrel and a 25- $\mathrm{cm}(9-7 / 8-\mathrm{in}$.) Smith tungsten-carbide 4 -cone bit. The cut core is $5.7 \mathrm{~cm}(2-1 / 4 \mathrm{in}$.) 0D. This system was developed by Scripp for coring the ocean bottoms. It was used with high recovery on the LASL Hot Dry Rock Project, coring granitic rock. It had not previously been tried in the sedimentary rock which occurs at Raft River. Recovery percentage was better in the deeper, more indurated sediment. 
The first core attempt occurred at a depth of $577 \mathrm{~m}(1894 \mathrm{ft})$. The 37-cm (12-1/4-in.) corebarre1 stabilizer stuck at $442 \mathrm{~m}$ (1450 ft). Apparently either a dogleg or out-of-gauge hole caused the problem. On reentry with a 28-cm (11-in.) stabilizer, a core was successfully taken. Coring depth was from 577 to $579 \mathrm{~m}$ (1894 to $1901 \mathrm{ft}$ ); recovering $1 \mathrm{~m}(3.5 \mathrm{ft}$ ) of micaceous sandstone.

A third core attempt occurred at $643 \mathrm{~m}(2110 \mathrm{ft})$ after drilling out the shoe. An obstruction occurred at $575 \mathrm{~m}$ (1887 ft) on the trip in the hole with the corebarre1. The obstruction was later determined to be parted casing.

Coring was not attempted again until a depth of $860 \mathrm{~m}(2820 \mathrm{ft})$. Six meters $(20 \mathrm{ft})$ were cored, recovering $4 \mathrm{~m}(13 \mathrm{ft})$ of fractured micaceous sandstone and siltstone.

On the reentered well (RRGP-4), two cores were recovered in two adjacent 5-m (15-ft) intervals using Hycalog 20-cm (7-7/8-in.) bits of Types CMHIP and PC20P. Recovered core sections were $3 \mathrm{~m}(9 \mathrm{ft})$ and $2 \mathrm{~m}(7 \mathrm{ft})$ in length, taken between 1414 and $1424 \mathrm{~m}(4640$ and $4671 \mathrm{ft})$. The core was taken at the interface between the tertiary and the $P-C$ metamorphic formations.

\section{DRILLING FLUID}

Approximately $1 \mathrm{~kg} / \mathrm{L}$ ( 8 to $9 \mathrm{lb} / \mathrm{ga} 1$ ) of ge1 mud, viscosity 41 , was used to drill the surface hole. Gel mud was used to drill the $44-\mathrm{cm}(17-1 / 2-i n$. hole to $579 \mathrm{~m}(1901 \mathrm{ft})$. Mud weight was held at $1.2 \mathrm{~kg} / \mathrm{L}(9.51 \mathrm{~b} / \mathrm{ga} 1)$ with a viscosity of from 36 to $52 \mathrm{sec} / 1000 \mathrm{~cm}^{3}$. Drilling below $582 \mathrm{~m}$ (1909 ft) was performed with water from a domestic well and the reserve pit at the RRGE-1 site.

\section{SAMPLE LOGGING}

A mud logging service monitoring drilling fluid and cutting returns was utilized throughout all drilling below the conductor pipe. This service monitored fluid temperatures (in and out), and hydrogen sulfide. Lithologic characteristics were also determined by analyzing the drill cuttings recovered every $6 \mathrm{~m}(20 \mathrm{ft})$. Readers of reports which have not been provided with copies of the lithologic logs may obtain copies by writing to the office of Geothermal Energy, Idaho Operations Office, Department of Energy, 550 Second Street, Idaho Falls, ID 83401.

\section{FORMATION TOPS}

Formations were encountered at the following drilled depths:

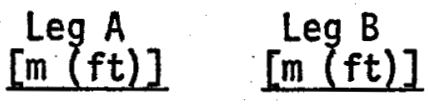

Alluvium

Raft River

Salt Lake

Yost Quartzite

Shist (Upper Narrows)

Elba Quartzite

Quartz Monzonite
Surface Surface

$\begin{array}{rrrr}27 & (90) & 27 & (90) \\ 300 & (1000) & 300 & (1000) \\ 1399 & (4590) & -- & -- \\ 1419 & (4655) & 1416 & (4645) \\ 1451 & (4760) & 1468 & (4815) \\ 1539 & (5050) & 1548 & (5080)\end{array}$




\section{LOGGING}

Various logs were run in the RRGI- 6 well in order to determine the condition of the hole at different stages of the drilling operations. A listing of the logs, the intervals, and the lengths is shown in the following tables.

\section{TABLE I}

LOG RECORD, 0 to 580 METERS ( 0 to 1900 FEET)

\begin{tabular}{|c|c|c|c|c|}
\hline Date & Type & Depth (m) & Depth (ft) & Company \\
\hline $4-17-77$ & $\begin{array}{l}\text { Compensated } \\
\text { Neutron }\end{array}$ & $122-582$ & $401-1909$ & Dresser-Atlas \\
\hline $4-6-77$ & Densilog & $122-581$ & $400-1908$ & Dresser-Atlas \\
\hline $4-15-77$ & $\begin{array}{l}\text { Dua 1 } \\
\text { Induction }\end{array}$ & $123-575$ & $403-1886$ & Dresser-Atlas \\
\hline $4-16-77$ & Acoustilog & $122-580$ & $401-1901$ & Dresser-Atlas \\
\hline
\end{tabular}


TABLE II

LOG RECORD, 550 TO 1065 METERS ( 1800 TO 3500 FEET)

\begin{tabular}{clrrr}
\hline Date & \multicolumn{1}{c}{ Type } & Depth $(\mathrm{m})$ & Depth $(\mathrm{ft})$ & Company \\
$9-28-78$ & $\begin{array}{l}\text { Dual Induction } \\
\text { Focused }\end{array}$ & $556-1055$ & $1824-3460$ & Dresser-Atlas \\
$9-27-78$ & Caliper & $533-1056$ & $1815-3464$ & Dresser-Atlas \\
$9-29-78$ & Acoustilog & $555-1051$ & $1820-3448$ & Dresser-Atlas \\
$9-28-78$ & Densilog & $555-1053$ & $1820-3456$ & Dresser-Atlas \\
$9-28-78$ & Densilog-Neutron & $555-1053$ & $1820-3456$ & Dresser-Atlas \\
$9-28-78$ & $\Delta$ Temperature & $0-1056$ & $0-3463$ & Dresser-Atlas \\
$10-5-78$ & Cement Bond & $442-950$ & $1450-3118$ & Dresser-Atlas \\
$10-2-78$ & Cement Bond & $442-990$ & $1450-3247$ & Dresser-Atlas \\
& & $\underline{4 A B L E}$ III & &
\end{tabular}

LOG RECORD, LEG A, 1020 TO 1650 METERS (3350 TO 5420 FEET)

\begin{tabular}{|c|c|c|c|c|}
\hline Date & Type & Depth (m) & Depth (ft) & Company \\
\hline $10-20-78$ & Densilog & $1058-1591$ & $3471-5221$ & Dresser-Atlas \\
\hline $10-20-78$ & Caliper & $1054-1585$ & $3459-5200$ & Dresser-Atlas \\
\hline $10-20-78$ & $\begin{array}{l}\text { Compensated } \\
\text { Neutron }\end{array}$ & $1059-1590$ & $3474-5220$ & Dresser-Atlas \\
\hline $10-20-78$ & $\begin{array}{l}\text { Dual Induction } \\
\text { Focused }\end{array}$ & $1052-1590$ & $3450-5218$ & Dresser-Atlas \\
\hline $10-19-78$ & Temperature & $1042-1594$ & $3420-5230$ & Dresser-Atlas \\
\hline $10-29-78$ & $\begin{array}{l}\text { Differential } \\
\text { Temperature }\end{array}$ & $1036-1652$ & $3400-5420$ & Dresser-Atlas \\
\hline $10-20-78$ & Diplog & $1057-1581$ & $3467-5186$ & Dresser-Atlas \\
\hline $10-20-78$ & Acoustilog & $1057-1587$ & $3467-5208$ & Dresser-Atlas \\
\hline $\begin{array}{c}10-18-78 \\
\text { to } \\
10-30-78\end{array}$ & Mudlog, Leg A & $600-1652$ & $1970-5420$ & $\begin{array}{l}\text { Rocky Mountain } \\
\text { Geo-Engineering }\end{array}$ \\
\hline
\end{tabular}




\section{TABLE IV}

LOG RECORD, LEG B, 1020 T0 1560 METERS ( 3350 TO 5115 FEET)

\begin{tabular}{|c|c|c|c|c|}
\hline Date & Type & Depth (m) & Depth (ft) & Company \\
\hline $\begin{array}{c}10-31-78 \\
\text { to } \\
11-13-78\end{array}$ & Mudlog, Leg B & $1084-1650$ & $3555-5115$ & $\begin{array}{l}\text { Rocky Mountain } \\
\text { Geo-Engineering }\end{array}$ \\
\hline $11-13-78$ & $\begin{array}{l}\text { High Resolution } \\
\text { Temperature }\end{array}$ & $10-1563$ & $32-5128$ & Schlumberger \\
\hline $11-13-78$ & Dual Induction & $1058-1560$ & $3471-5120$ & Schlumberger \\
\hline $11-13-78$ & $\begin{array}{l}\text { Compensated } \\
\text { Sonic }\end{array}$ & $1043-1649$ & $3421-5113$ & Schlumberger \\
\hline $11-13-78$ & F.B. Spinner & $1029-1280$ & $3376-4200$ & Schlumberger \\
\hline $11-31-78$ & $\begin{array}{l}\text { Fracture I.D. } \\
\text { Log[a] }\end{array}$ & $1058-1561$ & $3470-5124$ & Schlumberger \\
\hline $11-13-78$ & $\begin{array}{l}\text { Compensated } \\
\text { Neutron } \\
\text { Formation } \\
\text { Density }\end{array}$ & $1058-1561$ & $3470-5120$ & Schlumberger \\
\hline $11-14-78$ & 4-Arm Caliper & $1058-1561$ & $3470-5124$ & Schlumberger \\
\hline $11-13-78$ & Directional & $1058-1561$ & $3470-5124$ & Schlumberger \\
\hline $10-29-78$ & $\begin{array}{l}\text { Differential } \\
\text { Temperature }\end{array}$ & $1036-1652$ & $3400-5420$ & Dresser-Atlas \\
\hline $10-20-78$ & Diplog & $1064-1561$ & $3490-5124$ & Dresser-Atlas \\
\hline $6-9-78$ & Flowmeter & -- & $0-T D$ & EG\&G \\
\hline \multirow[t]{2}{*}{$7-5-78$} & Pressure & -- & $0-T D$ & EG\&G \\
\hline & Temperature & --- & 0-TD & EG\&G \\
\hline
\end{tabular}

$[\mathrm{a}]_{\text {Computer processed interpretation. }}$ 


\section{CEMENTING}

Surface Casing -- The 51-cm (20-in.) casing was cemented in one stage with the guide shoe at $122 \mathrm{~m} \mathrm{GL}$ (400 ft) with 630 sacks of 50-50 Pozmix, $35 \%$ flour, and $2 \%$ calcium chloride. Slurry weight was $1.9 \mathrm{~kg} / \mathrm{L}$ (15.1 $\mathrm{lb} / \mathrm{gal})$, and yield was $0.041 \mathrm{~m}^{3}\left(1.44 \mathrm{ft}^{3}\right)$ per sack. Nine thousand 1iters ( $60 \mathrm{bbi})$ of water were pumped ahead of the slurry displacing the gel. Pumping was started at 4:05 A.M., with cement in place (CIP) at 5:20 A.M. Good circulation was maintained throughout the operation, and cement returns were obtained at the surface.

Intermediate Casing -- The 34-cm (13-3/8-in.) casing was cemented in two stages. The shoe was set at $597 \mathrm{~m} \mathrm{GL}$ (1901 ft). A differential valve (DV) cementing tool was placed at $426 \mathrm{~m}$ (1397 ft). The cement was Class-G cement with $35 \%$ silica flour and $0.03 \%$ Hallad 9 , for a weight of $1.9 \mathrm{~kg} / \mathrm{L}$ ( $15.1 \mathrm{lb} / \mathrm{gal})$, with $9000 \mathrm{~L}(60 \mathrm{bbl})$ of water ahead. Pumping pressure was 2000 to $3500 \mathrm{kPa}$ ( 300 to $500 \mathrm{psi}$ ), increasing to $9000 \mathrm{kPa}$ (1250 psi) when the plug was set. Pumping started at 8:42 P.M. with CIP at 10:10 P.M. The crew waited on cement (WOC) for 8 hours between stages. The second stage started at 7:00 A.M. with CIP at 8:15 A.M. There were $9000 \mathrm{~L}$ (60 bbl) of water ahead of slurry: 1013 sacks of 50-50 Pozmix, with $35 \%$ silica flour displaced by water followed by mud. Initial pumping pressures of 5000 to $5200 \mathrm{kPa}$ ( 700 to $750 \mathrm{psi}$ ) jumped to $10,300 \mathrm{kPa}$ (1500 psi) when the plug was bumped. Good circulation and returns were experienced throughout both cementing jobs.

\section{LINER HANGER}

The liner hanger for the 25-cm (9-5/8-in.) production liner was a BaashRoss plain type, with fluted cones and circulation ports. The ports were designed to facilitate a remedial cement job if required.

Forty-eight joints of $25-\mathrm{cm}(9-5 / 8-\mathrm{in}),. \mathrm{K}-55,54-\mathrm{kg} / \mathrm{m}(36-1 \mathrm{~b} / \mathrm{ft})$, $B T \& C$ casing totaling $593 \mathrm{~m}(1945 \mathrm{ft})$ were hung from the liner hanger inside the 34-cm (13-3/8-in.) casing. The liner hanger was set at $461 \mathrm{~m}(1512 \mathrm{ft})$, leaving an overlap of $123 \mathrm{~m}(403 \mathrm{ft})$ between the 34- $\mathrm{cm}(13-3 / 8-i n$.$) casing and the 25-cm (9-5/8-in.) casing. The shoe of$ the 25-cm (9-5/8-in.) liner was set at $1054 \mathrm{~m}$ (3457 ft). A float collar was positioned one joint above the float shoe. (See details on centralizers in the Appendix.) A11 casing ends were threaded and joined with couplings. A casing crew using the "JAM" (Joint Analyzed Make-Up) system was employed to run the $25-\mathrm{cm}(9-5 / 8-i n$.$) casing.$ 


\section{DRILLING PROBLEMS}

Stuck Corebarrel -- While running with the corebarrel on the first core run, the 37-cm OD (12-1/4-in.) core assembly stabilizer immediately above the corebarrel became stuck at $442 \mathrm{~cm}(1450 \mathrm{ft})$. The stabilizer was located $11 \mathrm{~m}(34 \mathrm{ft})$ above the bit. Working the drill pipe did not free the stabilizer. Dialog Shot Service was called out. While waiting on Dialog, 153,000 L (1000 bbl) of diesel oil were spotted, but the wait time was too short for the diesel to do much good. Dialog set off two string shots at $441 \mathrm{~m}(1448 \mathrm{ft})$. The drill pipe was backed off the core assembly. The hole was entered with Bowen 20-cm (8-in.) jars and bumper sub, and screwed back into the core assembly. The jars were set off and the core assembly was retrieved. A 28-cm OD (11-in.) stabilizer replaced the $31-\mathrm{cm}(12-1 / 4-i n$.$) stabilizer for future coring.$

Parted Casing -- A 28-hour WOC followed the cementing of the $34-\mathrm{cm}$ (13-3/8-in.) casing before drilling out the cement. Drilling took 4-1/2 hours, with casing pressure tests of $2000 \mathrm{kPa}$ (300 psi). The hole was deepened to $643 \mathrm{~m}(2110 \mathrm{ft})$, when it became apparent the bit was worn. During the following trip into the hole, an obstruction was encountered at $575 \mathrm{~m}(1887 \mathrm{ft})$. The obstruction was thought to be a loosened casing shoe, or possibly a collapsed casing. Drillers attempted to mill the obstruction, but hole conditions improved little. Petrolog was called out to run caliper, collar-locator, and cement-bond logs. The caliper log definitely determined that the casing shoe and two joints of casing had parted and fallen downhole $20 \mathrm{~m}(67 \mathrm{ft})$. The top of the parted casing was at $575 \mathrm{~m}(1887 \mathrm{ft})$. The collar-locator log determined that there was a collar at the bottom of the cemented casing looking down toward the parted section. The cement-bond $\log$ showed good bond to approximately $533 \mathrm{~m}(1750 \mathrm{ft})$, and about $70 \%$ bonding below $533 \mathrm{~m}$ $(1750 \mathrm{ft})$.

It appears that at least three things caused the casing to part. Any one of the events would probably not have caused problems; in combination, however, the events caused the casing to part. The formations of the upper zones were semi-consolidated, and they did not place the casing shoe in indurated beds. The cement was over-retarded. The dril1 cuttings showed that the cement was still soft days later. Also, the poor bond identified by the cement-bond $10 \mathrm{~g}$ indicated the cement bond was broken because the annular cement was soft during the drilling of the cement inside the casing. The high makeup torque on the joint that parted could have cracked the collar or sheared the lower casing threads. It is also possible that the soft cement would not hold the casing, and the rotating action of the bit inside the casing unthreaded (backed off) the casing. In either case, the soft cement could not hold the casing and allowed the casing to drop. 
Attempts to mill the casing caused sidetracking around the parted casing on the low side. The hole was simultaneously enlarged by washout due to the drilling-fluid action. The large hole diameter at the top of the parted casing made entry into the casing difficult.

Prior to completion of the injection well, four joints of $25-\mathrm{cm}$ (9-5/8-in.) casing with modified guide shoe were run into the hole. The casing was successfully passed through the parted 34-cm (13-3/8-in.) casing. This verified the well could be deepened and completed at a later date utilizing a $25-\mathrm{cm}$ (9-5/8-in.) liner.

Lost Logging Tool -- While logging Leg A, the logging cable parted, dropping the acoustic tool to the bottom. Later, while coming up the hole with a tool, a stabilizer spring and collar were pulled loose at the liner hanger. Two fishing attempts retrieved $9 \mathrm{~m}(28 \mathrm{ft})$ of the acoustic tool. One mill and two magnet runs cleaned the hole for further drilling.

Lost Monel Drill Collar -- While building the shoulder for Leg B, the box end of the Monel collar broke. Fishing tools were ordered, and one fishing run recovered the collar at $1470 \mathrm{~m}$ (4831 ft): $185 \mathrm{~m}(606 \mathrm{ft})$ off the bottom.

\section{INJECTION TEST}

At a depth of $866 \mathrm{~m}(2840 \mathrm{ft})$, a preliminary injection test was run for 5 hours, utilizing the two rig pumps (see Figure 7 ). Pump One operated at $22.9 \mathrm{~L} / \mathrm{stroke}(6.3 \mathrm{gal} / \mathrm{stroke})$, and Pump Two delivered $9.4 \mathrm{~L} / \mathrm{stroke}$ (2.6 gal/stroke) at $90 \%$ efficiency. The initial wellhead pressure was $220 \mathrm{kPa}$ (32 psi). The test was run by periodically stepping up strokes to a maximum output of $932 \mathrm{~L} / \mathrm{sec}(534 \mathrm{gpm})$. The maximum pressure recorded was $540 \mathrm{kPa}$ (78 psi). The strokes were then step-reduced to zero. Pressure returned to $220 \mathrm{kPa}$ (32 psi) within one hour of shut-in. The formations appeared to accept fluid more readily with time. 


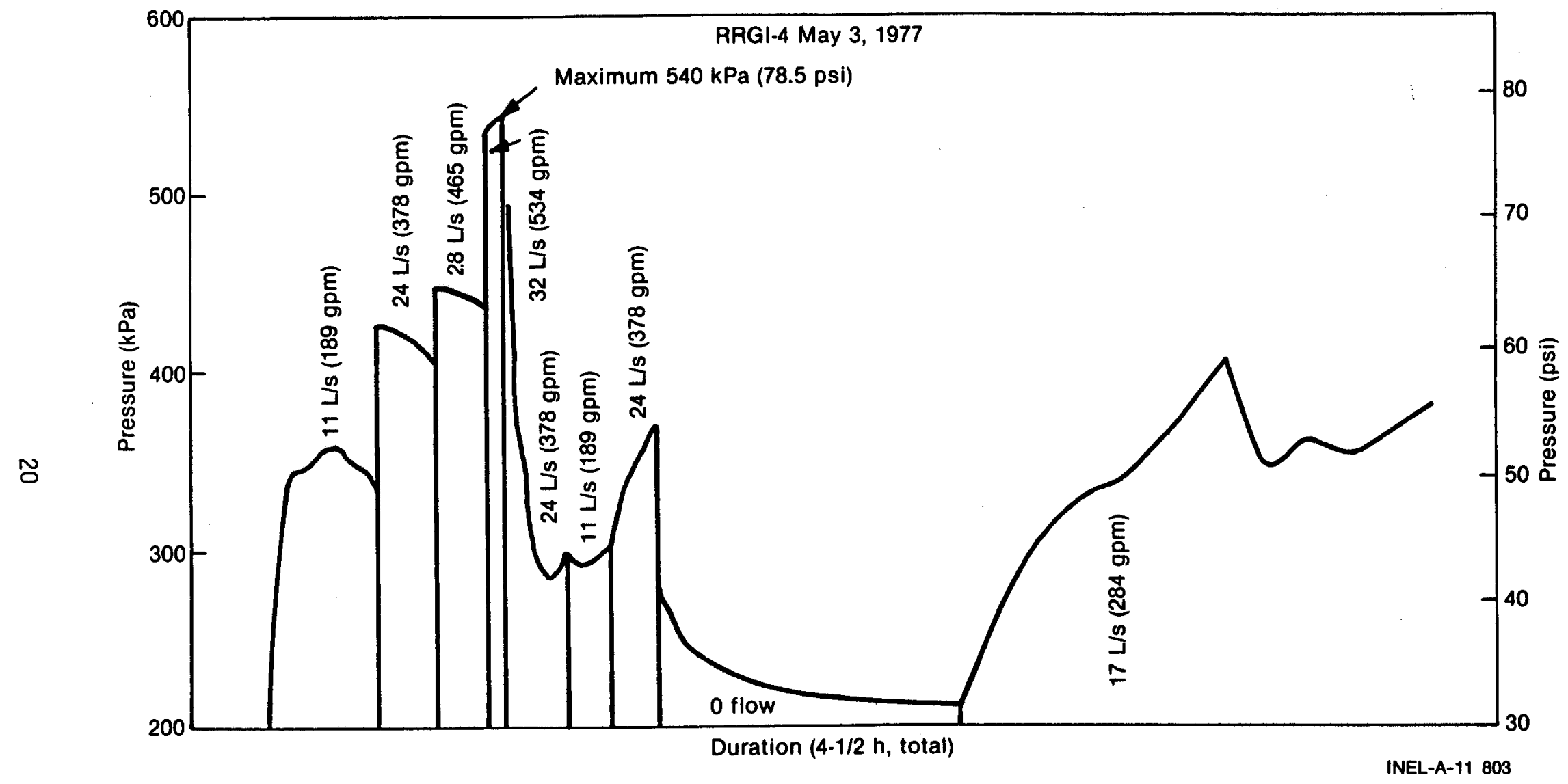

Fig. 7 Injection pump test. 
APPENDIX A

DAILY DRILLING REPORTS

The following tables contain excerpts from the notes recorded in the driller's IADC "Daily Drilling Report."

\section{TABLE A-I}

DAILY DRILLING REPQRTS

$\underline{\text { RRGI-4 }}$

March 31, 1977

Cellar completed.

Apri] 3, 1977

Rat, mouse, and conductor set.

Apri1 4, 1977

Rig on location.

April 5 to 7,1977

Rigged up Colorado Well Service Rig \#99, a Cabot 900 with $34-m(112-f t)$ derrick. Substructure was $4 \mathrm{~m}(14 \mathrm{ft})$ above ground level. Stabilization equipment was on location. Water line laid from RRGE- 1 to location.

Apri1 8, 1977

Spudded. Drilled 38-cm (15-in.) hole from $13 \mathrm{~m}$ (44 ft) to $728 \mathrm{~m}$ (419 ft) (Kelly Bushing) in 10 hours $[a]$. Center punched with $66-\mathrm{cm}$ (26-in.) hole opener to start hole. Drilled with 10 $16-\times 6-\mathrm{cm}(6-1 / 2-\times 2-1 / 4-i n$.$) drill collars.$ The $20-\mathrm{cm}(8-i n$.$) collars from Nevada Test Site$ (NTS) had not arrived. Drilled with Pump 1 20- $\times$ 47-cm (7-3/4- x 16-in.) Ideco 700-MM Pump with $15-\mathrm{cm}$ (6-in.) liners at 53 strokes per minute (SPM). Pump 2 is an $18-\times 36-\mathrm{cm}$ (7- x 14-in.) Gardner Denver.

April 9, 1977

Drilled 66-cm (26-in.) hole from $13 \mathrm{~m}(44 \mathrm{ft})$ to $58 \mathrm{~m}$ (190 ft). Drill collars: 1 monel, 8 steel $20-\times 8-\mathrm{cm}(7-3 / 4-\times 3-i n$.$) . Bit 66-\mathrm{cm}(26-\mathrm{in.})$ Hole Opener ( $\mathrm{HO}$.

[a] Al1 depths referenced to Kelly Bushing (KB) $4 \mathrm{~m}(14 \mathrm{ft}$ ) above ground level unless specified. 
Apri1 10, 1977

Apri1 11, 1977

April 12, 1977

April 13, 1977

Apri1 14, 1977

Apri1 15, 1977

April 16, 1977
Drilled 66-cm (26-in.) hole to $125 \mathrm{~m}(410 \mathrm{ft})$ in 8 hours. Circulated $2-1 / 2$ hours; took 2-1/2-hour trip to lay down tools and hole opener, and 11 hours to run in $51-\mathrm{cm}(20-\mathrm{in}$. casing with Parrish $0 i 1$ tool. Had to spud and wash from $21 \mathrm{~m}(70 \mathrm{ft})$ to bottom. Probable dogleg at $21 \mathrm{~m}(70 \mathrm{ft})$.

Ran casing ( $2-1 / 2$ hours). Totaled 10 joints of $51-\mathrm{cm}(20-\mathrm{in}.) \mathrm{H}-40104-\mathrm{kg} / \mathrm{m}(94-1 \mathrm{~b} / \mathrm{ft})$ casing; welded and tacked each joint. Circulated 45 minutes to bottom: $124 \mathrm{~m}$ ( $407 \mathrm{ft})$ GL. Cemented casing.

Waited on concrete (WOC) 8 hours while installing bradenhead, $51-\mathrm{cm}$ (20-in.) expansion spool, $51-\mathrm{cm}(20-i n$.$) single-gate BOP, and flow nipple.$ Nippled up for 1/2-hour pressure test. Held $2000 \mathrm{kPa}(300 \mathrm{psi})$ for 15 minutes. Made up tools and tripped in hole. Drilled cement, shoe, and float collar. Drilled to $160 \mathrm{~m}$ $(526 \mathrm{ft})$. Two-hour trip for plugged bit.

Drilled 31-cm (12-1/4-in.) hole to $444 \mathrm{~m}$ (1456 ft).

Drilled to $582 \mathrm{~m}$ (1908 ft). Made up Joides corebarrel system.

Made 2-hour trip in with corebarrel. Stuck tool at stabilizer at $442 \mathrm{~m}(1450 \mathrm{ft})$. Worked pipe 14 hours. Spotted with $3630 \mathrm{~L}(1,000 \mathrm{ga} 1)$ diesel fuel. Took 8 hours to rig up Dialog; set off 2 string shots at $441 \mathrm{~m}(1448 \mathrm{ft})$. Backed off corebarrel and stabilizer. Tripped out. Went in hole with Bowen 20-cm (8-in.) jars and bumper sub. Screwed into fish. Set off jars one time. Started out with fish.

Took 4-hour trip out with fish; recovered everything. Took 8 hours to log hole with DresserAtlas. Mud gelled due to BHT and standing in hole. Tripped in hole, circulated, and conditioned hole. Dresser continued to log the hole. 
Apri1 17, 1977

Apri1 18, 1977

Apri1 19, 1977

April 20, 1977

April 21, 1977

April 22, 1977

April 23, 1977
Completed logging. Picked up corebarrel. Tripped in hole. . Cored $5 \mathrm{~m}(15 \mathrm{ft})$ and recovered $1 \mathrm{~m}(3.5 \mathrm{ft})$ of core.

Opened 31-cm (12-1/4-in.) hole with 44-cm $(17-1 / 2-i n$.$) hole opener to 399 \mathrm{~m}(1310 \mathrm{ft})$.

Opened hole $586 \mathrm{~m}$ (1923 ft).

USGS attempted caliper log unsuccessfully for 6 hours. Took 12 hours to rig-up Lamb "JAM" system and run 49 joints of $34-\mathrm{cm}(13-3 / 8-\mathrm{in}$. $\mathrm{K}-55,81-\mathrm{kg} / \mathrm{m}(54.5-\mathrm{lb} / \mathrm{ft})$ casing, plus guide shoe, float collar, and DV tool. Stage cemented with $9180 \mathrm{~L}$ (60 bbi) water ahead, 368 sacks pozmix, $35 \%$ silica flour and $0.03 \%$ Hallad 9 . Circulated 2 hours through ports and DV tool. Circulated excess cement to surface and continued to circulate with gel while wOC.

WOC 6 hours between stages. Took 2 hours to cement second stage through DV tool at $426 \mathrm{~m}$ (1397 ft) to surface with 1013 sacks of Poz mix with $35 \%$ silica flour. Nippled up BOP equipment.

Nippled up BOP. Installed expansion spool, master gate, adapter spool, double-gate Shaffer BOP, Grant rotating head, and flow line.

Pressure-tested system for $1 / 2$ hour at $2000 \mathrm{kPa}$ (300 psi) with master gate valve closed. Pressure-tested system after drilling DV tool with Hydril closed at $2000 \mathrm{kPa}$ (300 psi) for 15 minutes. Drilled with water to $617 \mathrm{~m}$ $(2025 \mathrm{ft})$.

Drilled $31-\mathrm{cm}(12-1 / 4-\mathrm{in}$.$) to 647 \mathrm{~m}(2124 \mathrm{ft})$. Tripped in with corebarrel:. Hit obstruction at $579 \mathrm{~m}(1901 \mathrm{ft})$. Worked bit through while rotating. There was no drag on pull back. Worked through several times with no improvement. Tripped out (corebit still in good condition). Ran in hole and worked through tight spot. No improvement. Pipe torqued up and backed off. Tripped out to check. Backed off 15 stands ( 30 joints) down. Tripped in and screwed into tool. Bit lodged at $579 \mathrm{~m}(1901 \mathrm{ft})$. Tripped out. Tripped in and hit junk at $579 \mathrm{~m}$ (1901 ft). Attempted unsuccessfully to work through it. 
Table A-I (Cont.)

April 24, 1977

Apri1 25, 1977

April 26, 1977

Apri1 27, 1977
Tripped out. Waited on milling tools. Picked up flat-bottom mill and tripped in hole. Hit junk at $579 \mathrm{~m}(1901 \mathrm{ft})$. Milled 5 hours: 579 to $582 \mathrm{~m}$ (1901 to $1909 \mathrm{ft}$ ). Worked back and forth. Kept hanging up at $579 \mathrm{~m}$ (1901 ft). Tripped out.

Picked up tapered mill and stabilizer. Hit junk at $579 \mathrm{~m}$ (1901 ft). Drilled and worked tapered mill to $593 \mathrm{~m}$ (1946 ft) until mill would go without rotating. Well was flowing.

Tripped out with tapered mill and tripped in with flat-bottom mill, junk sub, and stabilizer. Milled from 579 to $582 \mathrm{~m}$ (1901 to $1909 \mathrm{ft}$ ). Tripped out and layed down tools. Rigged up to run electric log (EG\&G). Logged two hours. Ran in hole with tapered mill and stabilizer. Hit junk at $579 \mathrm{~m}(1901 \mathrm{ft})$. Worked through to $\mathrm{fill}$ at $629 \mathrm{~m}(2065 \mathrm{ft})$ : Washed out fill to $647 \mathrm{~m}$ (2124 ft) and circulated to bottom. Called out petrolog to run collar log, cement bond, and caliper $\log$ in order to diagnose situation.

Tripped out with tapered mi11. Petrolog ran logs 8 hours. Ran caliper, collar locater, and cementbond logs. Determined bottom 2 joints of $34-\mathrm{cm}$ (13-3/8-in.) casing had parted and had fallen down hole with male end looking up. Top of fish was at $579 \mathrm{~m}$ (1901 ft). Bottom of cemented casing was at $559 \mathrm{~m}$ (1835 ft). Collar was looking down. Ran 6-hour temperature log with EG\&G logging unit. Temperature was $113.5^{\circ} \mathrm{C}$ $\left(236.5^{\circ} \mathrm{F}\right)$ at top of parted casing. Well was flashing. Installed Hughes bit guide and tripped in hole to $579 \mathrm{~m}$ (1901 ft). Worked bit through top of fish. Found no fill and very little junk. Drilled to $861 \mathrm{~m}(2235 \mathrm{ft})$.

Drilled to $745 \mathrm{~m}(2445 \mathrm{ft})$. Lost all circulation at $745 \mathrm{~m}(2445 \mathrm{ft})$. This came back about $50 \%$. Tripped out, picked up corebarrel. Could not tag casing at $579 \mathrm{~m}(1901 \mathrm{ft})$. Tripped out and picked up bit. Ran in hole to $579 \mathrm{~m}(1901 \mathrm{ft})$ and attempted unsuccessfully to work through $34-\mathrm{cm}$ (13-3/8-in.) casing; kept falling off side of 34-cm (13-3/8-in.) casing. 
Table A-I (Cont.)

April 28, 1977

Apri1 29, 1977

Apri 130,1977

May 1, 1977
Could not get inside 34-cm (13-3/8-in.) casing at $579 \mathrm{~m}$ (1901 ft). Picked up bit, stabilizer, 2 drill collars, stabilizer, and 6 drill collars, and tripped into hole. Failed to work through casing at $579 \mathrm{~m}$ (1901 ft); tripped out. Wel1 was flashing. Pumped cool water down hole. Tripped into hole with tapered mill. Spent 2 hours trying to work through casing at $579 \mathrm{~m}$ (1901 ft). Tripped out. Waited on spear for 34-cm (13-3/8-in.) casing.

Made up tools. Started in hole. Slips were too large. Broke down spear, waited on smaller slips. Dressed spear in 1 hour. Tripped in hole with bent 9-cm (3-1/2-in.) dril1-pipe stinger, 4-m ( $13-\mathrm{ft}$ ) spear, 2 drill collars, jars and 6 drill collars. Spent 2 hours working on spear in 34-cm (13-3/8-in.) casing at $579 \mathrm{~m}$ (1901 ft). Could not set spear, so tripped out. One spring on setting device had broken off. Replaced spring. Tripped in hole. Worked spear in 34-cm (13-3/8-in.) casing. Worked pipe and set off jars. Could not move fish. Tripped out of hole.

Picked up bit with jars and ran into hole to $579 \mathrm{~m}(1901 \mathrm{ft})$. Worked through $34-\mathrm{cm}$ (13-3/8-in.) casing and to $728 \mathrm{~m}(2390 \mathrm{ft})$. Cleaned fill from bottom and drilled to $864 \mathrm{~m}$ $(2834 \mathrm{ft})$. Tried 8 hours to flow well for maximum temperature buildup. No flow. Ran temperature survey: $82^{\circ} \mathrm{C}\left(180^{\circ} \mathrm{F}\right)$ maximum at $518 \mathrm{~m}(1700 \mathrm{ft})$.

Tripped out, picked up corebarrel, shock sub, and collars, and tripped in hole. Worked through 34-cm (13-3/8-in.) casing at $579 \mathrm{~m}$ (1901 ft). Went to $855 \mathrm{~m}(2806 \mathrm{ft})$. Cleaned out fill to TD and cored $6 \mathrm{~m}(20 \mathrm{ft})$. Tripped out and emptied corebarre1. Recovered $7 \mathrm{~m}(13 \mathrm{ft})$. Tripped in to $579 \mathrm{~m}$ (1901 ft). Attempted to work bit through. Tripped out. Tripped in with shock sub on bottom of collars. Attempted to work through at $579 \mathrm{~m}(1901 \mathrm{ft})$. Tripped out. 


\section{Table A-I (Cont.)}

May 2, 1977

May 3, 1977

May 4, 1977
Picked up tapered mill, float sub, and bent joint drill pipe. Tripped to $579 \mathrm{~m}$ (1901 ft). Attempted to work through casing. Got through with Kelly on, but had to pull back for connection and could not get back in. Tripped out. Ran temperature log.

Ran 5-hour step injection test using both rig pumps. Well thead pressure reached $345 \mathrm{kPa}$ (50 psi) at $30 \mathrm{SPM}$ and $11.4 \mathrm{~L} / \mathrm{sec}(189 \mathrm{gpm})$, and reached maximum of $538 \mathrm{kPa}(78 \mathrm{psi})$ at $120 \mathrm{SPM}$ and $32 \mathrm{~L} / \mathrm{sec}(534 \mathrm{gpm})$. Picked up four joints of 24-cm (9-5/8-in.) casing with modified shoe and ran to $579 \mathrm{~m}(1901 \mathrm{ft})$. Worked casing through 34-cm (13-3/8-in.) casing and down to $595 \mathrm{~m}$ $(1952 \mathrm{ft})$. Repaired wireline and tool on logging unit. Ran temperature $\log$ inside pipe. Maximum temperature was $122^{\circ} \mathrm{C}\left(252^{\circ} \mathrm{F}\right)$ at $823 \mathrm{~m}$ $(2700 \mathrm{ft})$.

Ran 8-hour injection test and cooled down the we11. Tripped out with drill pipe and 4 joints of casing with modified shoe. Casing run was made to verify that the well could be completed later as a production well. Broke down corebarrel. Layed down drill pipe and drill collars. closed master gate and rigged down. 
September 21, 1978

September 22, 1978

September 23, 1978

September 24, 1978

September 25, 1978

September 26, 1978

September 27, 1978

September 28, 1978

September 29,1978

September 30, 1978

October 1, 1978

October 2, 1978

October 3, 1978

October 4, 1978
Completed rig up over RRGI-4. Rigged up $20-\mathrm{cm}$ (8-in.) flow line. Redrilled the rat and mouse holes. Picked up bit and drill collars.

Picked up drill pipe and drilled by parted casing to $607 \mathrm{~m}(1990 \mathrm{ft})$. Tripped out to change bit.

Tripped into hole and drilled to $684 \mathrm{~m}(2245 \mathrm{ft})$.

Tripped out, to change bits and drilled to $834 \mathrm{~m}$ (2737 ft). Drilling quartz and siltstone.

Tripped out of hole for bit change. Changed Grant rotating head rubber and drilled to $927 \mathrm{~m}(3040 \mathrm{ft})$.

Drilled to $1000 \mathrm{~m}(3280 \mathrm{ft})$. Tripped out of hole for bit change. Ran survey. On each trip into hole it became easier to drop past the partial casing.

Drilled to $1056 \mathrm{~m}$ (3464 ft) in siltstone. Circulated to clean hole for logging. Tripped out of hole and prepared for loggers.

Logged well. Injected $48 \mathrm{~L} / \mathrm{sec}(800 \mathrm{gpm})$ into the well at $3500 \mathrm{kPa}$ (500 psi) while the temperaturelogging tool was in the well.

Completed logging hole and waited for Otis casing hanger.

Waited for Otis casing hanger.

Rigged up and ran 24-cm (9-5/8 in.) casing. Bottom of casing set at $1054 \mathrm{~m}$ ( $3457 \mathrm{ft})$. Casing hanger set at $461 \mathrm{~m}(1512 \mathrm{ft})$. Mixed 1450 sacks of cement. Completed cement job, but lost returns for 20 minutes. Layed down $20-\mathrm{cm}(8-\mathrm{in}$.$) collars and picked up 15-\mathrm{cm}$ (6-in.) collars.

Waited on cement, then drilled out cement from $415 \mathrm{~m}$ $(1360 \mathrm{ft})$ to $461 \mathrm{~m} .(1512 \mathrm{ft})$.

Cement bond log indicated no cement from casing hanger down to $560 \mathrm{~m}(1837 \mathrm{ft})$. Rigged up to cement down through casing hanger. Waited on cement.

Mixed 200 sacks cement and squeezed cement down through casing hanger. Pulled out packer. 
October 5, 1978

October 6, 1978

October 7, 1978

October 8, 1978

October 9, 1978

October 10,1978

October 11, 1978

October 12, 1978

October 13, 1978

October 14, 1978

October 15,1978

October 16, 1978

October 17, 1978
Ran cement-bond log. Measured no bond 558 to $523 \mathrm{~m}$ (1830 to $1715 \mathrm{ft}$ ), 20\% bond 523 to $461 \mathrm{~m}$ (1715 to $1512 \mathrm{ft}$ ). Ran bit in to see if hole was clear. Pressure-tested casing to $11,700 \mathrm{kPa}$ (1700 psi) with Halliburton rig, and found no leaks. Idaho Water Resource representative elected not to observe test.

Drilled through shoe to $1082 \mathrm{~m}(3550 \mathrm{ft})$. Tripped to prepare for whipstocking. Rigged up turbodri11 and tripped into hole.

Drilled and ran surveys to $1098 \mathrm{~m}(3620 \mathrm{ft})$. Tripped out to remove turbodri11. Tripped back into hole.

Drilled and ran surveys alternately to $1175 \mathrm{~m}(3853 \mathrm{ft})$. Circulated and tripped out of hole. Deviation was about $10-1 / 2$ degrees in a N5W direction.

Reamed to bottom and drilled to $1221 \mathrm{~m}(4006 \mathrm{ft}$ ) through quartz and siltstone.

Drilled to $1229 \mathrm{~m}(4032 \mathrm{ft})$. Tripped out to change out bottom hole reamer and bit. Drilled on to $1323 \mathrm{~m}$ $(4340 \mathrm{ft})$.

Drilled and took surveys to $1405 \mathrm{~m}(4608 \mathrm{ft})$. Tripped for bit change and drilled to $1443 \mathrm{~m}(4667 \mathrm{ft})$.

Drilled to $1489 \mathrm{~m}(4886 \mathrm{ft})$. Encountered quartz. Deviation at $1446 \mathrm{~m}(4746 \mathrm{ft})$ was 10 degrees in a N10W direction.

Drilled to $1508 \mathrm{~m}(4947 \mathrm{ft})$. Tripped for bit change, reamed back to bottom.

Drilled through quartz to $1530 \mathrm{~m}(5020 \mathrm{ft})$.

Drilled to $1545 \mathrm{~m}(5069 \mathrm{ft})$. Hung up on a key seat coming out of hole at $1148 \mathrm{~m}(3767 \mathrm{ft})$. Worked loose and tripped out. Picked up Dresser 6-point reamer. Reamed 1128 to $1167 \mathrm{~m}$ ( 3700 to $3830 \mathrm{ft}$ ) with key seat wiper. Reamed on down hole.

Reamed on to bottom of hole. Drilled ahead to $1562 \mathrm{~m}$ $(5124 \mathrm{ft})$.

Drilled to $1566 \mathrm{~m}$ (5138 ft). Tripped for bit change and drilled to $1574 \mathrm{~m}(5165 \mathrm{ft})$. Encountered quartz monzonite. 
October 18, 1978

October 19, 1978

October 20, 1978

October 21,1978

October 22, 1978

October 23, 1978

October 24, 1978

October 25, 1978

October 26, 1978

October 27, 1978

October 28, 1978

October 29, 1978

October 30, 1978

October 31,1978

November 1,1978
Drilled ahead to $1589 \mathrm{~m}(5212 \mathrm{ft})$. Took survey and tripped out for bit change. Reamed bottom part of hole, but got stuck $2 \mathrm{~m}(5 \mathrm{ft})$ off bottom.

Worked loose but could not get below stuck point. Circulated and waited on logging truck. Rigged up loggers.

Logged we 11. Logger lost 10-cm (4-in.) spring and steel sleave in hole. Lost acoustic logging tool in hole.

Completed logging. Fished for acoustical tool, but recovered only $2.4 \mathrm{~m}(8 \mathrm{ft})$ of the tool.

Went in with overshot but hit hanger. Tripped out. Overshot was split. Changed overshot and fished with no results. Tripped in again with another overshot and recovered $6 \mathrm{~m}(20 \mathrm{ft})$.

Tripped in and fished with no further results. Repair work done on rig.

Completed rig repairs. Completed trip in hole.

Milled 8 hours on junk. Tripped back in with magnet and recovered $14 \mathrm{~kg}$ (30 $\mathrm{lb})$ junk.

Made one more magnet run. Tripped in with new bit. No junk was encountered. Drilled to $1604 \mathrm{~m}$ (5263 ft).

Drilled to $1610 \mathrm{~m}(5283 \mathrm{ft})$ and tripped for bit change. Drilled on to $1629 \mathrm{~m}$ (5343 ft).

Drilled to $1654 \mathrm{~m}$ (5427 ft). Circulated hole in preparation for logging. Tripped out of hole.

Logged hole. Ran in hole and started to build shoulder for second leg.

Drilled $21 \mathrm{~m}(68 \mathrm{ft})$ on second leg shoulder. Tripped out, but left monel drill collar in hole. Flow-tested while awaiting fishing tools.

Made two fishing runs, recovering fish on second run. Tripped back into hole.

Drilled kickoff shoulder to $1106 \mathrm{~m}$ (3630 ft). Tripped out of hole. 


\section{TABLE A-II (cont.)}

November 2, 1978

November 3, 1978

November 4,1978

November 5, 1978

November 6,1978

November 7,1978

November $8 ; 1978$

November 9, 1978

November 10,1978

November 11,1978

November 12,1978

November 13, 1978

November 14, 1978

November $15, \quad 1978$
Picked up turbodrill and drilled to $1127 \mathrm{~m}(3697 \mathrm{ft})$. Tripped out of hole for bit change.

Reamed hole to TD and tripped for bit change. Drilled to $1210 \mathrm{~m}(3970 \mathrm{ft})$.

Drilled to $1222 \mathrm{~m}(4009 \mathrm{ft})$. Tripped to lay down turbodrill. Reamed back to $1222 \mathrm{~m}(4090 \mathrm{ft})$ with a 3-point reamer string key-seat wiper.

Drilled and ran surveys to $1409 \mathrm{~m}(4624 \mathrm{ft})$.

Drilled to $1414 \mathrm{~m}$ (4640 $\mathrm{ft}$ ). Tripped out and picked up core barrel. Cored $5 \mathrm{~m}(15 \mathrm{ft})$ and recovered $3 \mathrm{~m}$ ( $9 \mathrm{ft})$. Tripped back in to cut second core.

Cored $5 \mathrm{~m}(15 \mathrm{ft})$ of hole and recovered $2 \mathrm{~m}(7 \mathrm{ft})$ of core. Reamed core hole and drilled to $1454 \mathrm{~m}$ $(4770 \mathrm{ft})$.

Drilled to $1473 \mathrm{~m}(4833 \mathrm{ft})$. Tripped out for bit change. Reamed to bottom and drilled to $1474 \mathrm{~m}$ (4837 ft).

Dritled to $1503 \mathrm{~m}(4930 \mathrm{ft})$ and tripped out for bit and reamer change.

Dritred on to $1521 \mathrm{~m}$ (4991 ft).

Drilled to $1541 \mathrm{~m}(5056 \mathrm{ft})$. Reamed tight section of hole 1158 to $1280 \mathrm{~m}(3800$ to $4200 \mathrm{ft})$. Tripped out for bit change.

Drilled to 1559 $\mathrm{m}(5115 \mathrm{ft})$. Circulated hole for logging. Tripped out of hole. Hole was stilt tight around $1173 \mathrm{~m}\left(3850^{\circ} \mathrm{ft}\right)$.

Waited on Toggers. Began running: logs late.

Completed logging. Picked up turbodrilit, monel collar and 2-degree kick sub. Tried to orient tool to get back in Leg $A$, but failed to get in. Began laying down driti i pipe.

Completed laying down dri17 pipe. Started rig down. Released rig. 
APPENDIX B

BIT RECORD

The following tables provide a performance record for each of the bits used to drill Well Four. This information was also obtained from the IADC "Daily Drilling Report." 
TABLE B-I

BIT RECORD, RRGI-4

\begin{tabular}{|c|c|c|c|c|c|c|c|c|c|c|c|c|c|c|}
\hline Bit & Make & $\begin{array}{l}\text { Size } \\
{[\mathrm{cm}(\text { in. })]}\end{array}$ & Type & Jets & $\begin{array}{l}\text { Serial } \\
\text { Number }\end{array}$ & $\begin{array}{c}\text { Depth } \\
\text { Out } \\
{[\mathrm{m}(\mathrm{ft})]}\end{array}$ & $\begin{array}{l}\text { Total } \\
\text { Footage } \\
{[m(\mathrm{ft})]}\end{array}$ & Hours & $\begin{array}{c}\text { Weight } \\
{\left[\times 10^{3} \mathrm{~kg}\right.} \\
\left.\left(\times 10^{3} \quad 1 \mathrm{~b}\right)\right]\end{array}$ & RPM & $\begin{array}{l}\text { Pump Pres. } \\
{[\mathrm{kPa}} \\
\left(\mathrm{Ps}()^{\prime}\right]\end{array}$ & SPM & $\begin{array}{l}\text { Dull } \\
\text { Condition } \\
T / B / G \\
\end{array}$ & Remarks \\
\hline 1 & Security & $\begin{array}{l}38 \\
(15)\end{array}$ & S3J & $15 / 15 / 15$ & 687010 & $\begin{array}{c}128 \\
(419)\end{array}$ & $\begin{array}{c}114 \\
(375)\end{array}$ & 10 & $\begin{array}{l}1 / 7 \\
(3 / 75)\end{array}$ & 70 & $\begin{array}{l}2100 \\
(300)\end{array}$ & 53 & & Start RRGI-4 \\
\hline $2 A$ & Smith & $\left(12^{31} 1 / 4\right)$ & U2J & - & CD120 & $\begin{array}{c}128 \\
(419)\end{array}$ & $\begin{array}{c}114 \\
(375)\end{array}$ & 14 & (2) & 70 & $\begin{array}{l}2100 \\
(300)\end{array}$ & $48 / 90$ & & $\begin{array}{l}\text { With } 66 \mathrm{~cm}(26 \mathrm{in}) \\
\text { hole opener }\end{array}$ \\
\hline $2 B$ & Smith & $(121 / 4)$ & U2J & $14 / 14 / 14$ & 950EW & $\begin{array}{c}334 \\
(1097)\end{array}$ & $\begin{array}{c}225 \\
(739)\end{array}$ & 14 & $\begin{array}{c}7 \\
(15)\end{array}$ & 75 & $\begin{array}{l}2800 \\
(400)\end{array}$ & 54 & & $\begin{array}{l}\text { With } 66 \mathrm{~cm}(26 \mathrm{in}) \\
\text { hole opener }\end{array}$ \\
\hline 3 & Smith & $\left(12^{31} 1 / 4\right)$ & F2 & $14 / 14 / 15$ & $363 \mathrm{HW}$ & $\begin{array}{c}582 \\
(1908)\end{array}$ & $\begin{array}{c}247 \\
(811)\end{array}$ & $171 / 2$ & $\begin{array}{c}5 / 7 \\
(10 / 15)\end{array}$ & 70 & $\begin{array}{l}3100 \\
(450)\end{array}$ & 54 & & \\
\hline$-(R R)$ & Smith & $\left(12^{31} 1 / 4\right)$ & U2J & $14 / 14 / 15$ & 950EW & $\begin{array}{c}586 \\
(1923)\end{array}$ & $\begin{array}{c}458 \\
(1504)\end{array}$ & $361 / 2$ & $\left(\begin{array}{c}7 \\
(15)\end{array}\right.$ & 90 & $\begin{array}{l}3500 \\
(500)\end{array}$ & 56 & & $\begin{array}{l}\text { Reaming to } 44 \mathrm{~cm} \\
(171 / 2 \text { in })\end{array}$ \\
\hline $4(R R)$ & Smith & $\left(12^{31} 1 / 4\right)$ & U2J & $14 / 14 / 15$ & CD120 & $\begin{array}{c}647 \\
(2124)\end{array}$ & $\begin{array}{c}61 \\
(201)\end{array}$ & 11 & $\begin{array}{l}4 / 7 \\
(8 / 15)\end{array}$ & 90 & $\begin{array}{l}1400 / 3500 \\
(200 / 500)\end{array}$ & 56 & $7 / 6 / 8$ & \\
\hline 5 & Smith & $\left(12^{31} 1 / 4\right)$ & U2J & $14 / 14 / 15$ & Aj567 & - & $\begin{array}{c}0 \\
(0)\end{array}$ & 1 & $\overline{-}$ & - & - & - & $6 / 4 / 8$ & \\
\hline 6 & Smith & $\left(12^{31} 1 / 4\right)$ & U2J & $14 / 14 / 15$ & Au59] & - & - & - & - & - & $\div$ & - & - & \\
\hline 7 & Smith & $\left(12^{31} 1 / 4\right)$ & sWJ & $14 / 14 / 15$ & 1914DR & $\begin{array}{c}745 \\
(2445)\end{array}$ & $\begin{array}{c}98 \\
(321)\end{array}$ & 8 & $(75)$ & 90 & $\begin{array}{l}3500 \\
(500)\end{array}$ & 56 & & \\
\hline B & Smith & $\left(12^{31} 1 / 4\right)$ & SVJ & $14 / 14 / 15$ & $062 \mathrm{HC}$ & $\begin{array}{c}864 \\
(2834)\end{array}$ & $\begin{array}{c}119 \\
(389)\end{array}$ & 9 & $\begin{array}{c}5 / 7 \\
(10 / 15)\end{array}$ & 100 & $\begin{array}{l}4100 \\
(600)\end{array}$ & 56 & & \\
\hline 9 & Smith & $\left(12^{31} 1 / 4\right)$ & sVJ & $14 / 14 / 15$ & - & - & $(0)$ & - & $\begin{array}{c}5 \\
(10)\end{array}$ & $45 / 60$ & $\begin{array}{l}2500 \\
(350)\end{array}$ & 54 & & \\
\hline
\end{tabular}




\section{TABLE B-II}

BIT RECORD, RRGP-4

\begin{tabular}{|c|c|c|c|c|c|c|c|c|c|c|c|c|c|c|}
\hline - Bit & Make & $\begin{array}{c}\text { Size } \\
{[\mathrm{cm}(\text { ln. })]}\end{array}$ & Type & Jets & $\begin{array}{l}\text { Serial } \\
\text { Number }\end{array}$ & $\begin{array}{c}\text { Depth } \\
\text { Out } \\
{[\mathrm{m}(\mathrm{ft})]}\end{array}$ & $\begin{array}{l}\text { Total } \\
\text { Footage } \\
{[m(f t)]}\end{array}$ & Hours & 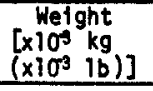 & RPM & $\begin{array}{c}\text { Pump Pres. } \\
{[\mathrm{kPa}} \\
(\mathrm{PS} 1)]\end{array}$ & SPM & $\begin{array}{c}\text { Dull } \\
\text { Condition } \\
T / B / G\end{array}$ & Remarks \\
\hline 1 & Smith & $\left(12^{31} 1 / 4\right)$ & SVH & Open & $592 \mathrm{KN}$ & $\begin{array}{c}607 \\
(1990)\end{array}$ & $\begin{array}{c}16 \\
(54)\end{array}$ & $131 / 2$ & $\begin{array}{c}5 \\
(10)\end{array}$ & 50 & $\begin{array}{r}5500 \\
(800)\end{array}$ & 50 & & Start RRGP-4 \\
\hline 2 & Smith & $\left(12^{31} 1 / 4\right)$ & SVH & Open & 963FA & $\begin{array}{c}684 \\
(2245)\end{array}$ & $\begin{array}{c}78 \\
(255)\end{array}$ & $201 / 2$ & $\left(\begin{array}{c}5 \\
(10)\end{array}\right.$ & 50 & $\begin{array}{r}5500 \\
(800)\end{array}$ & 50 & & \\
\hline 3 & Smith & $\left(12^{31} 1 / 4\right)$ & SVH & Open & $279 \mathrm{FB}$ & $\begin{array}{c}863 \\
(2832)\end{array}$ & $\begin{array}{c}179 \\
(587)\end{array}$ & 26 & $\stackrel{7}{(15)}$ & 60 & $\begin{array}{r}5500 \\
(800)\end{array}$ & 50 & $8 / 4 / 1 / 4$ & \\
\hline 4 & Smith & $\left(12^{31} 1 / 4\right)$ & SVHJ & Open & $638 \mathrm{FJ}$ & $\begin{array}{c}1000 \\
(3280)\end{array}$ & $\begin{array}{c}130 \\
(448)\end{array}$ & 23 & $\left(\begin{array}{c}7 \\
(15)\end{array}\right.$ & 60 & $\begin{array}{l}5500 \\
(800)\end{array}$ & 50 & & \\
\hline 5 & Hughes & $\left(12^{31} 1 / 4\right)$ & OWv & Open & FF880 & $\begin{array}{c}1056 \\
(3464)\end{array}$ & $\begin{array}{c}55 \\
(184)\end{array}$ & 18 & $\begin{array}{c}7 / 9 \\
(15 / 20)\end{array}$ & 60 & $\begin{array}{r}5500 \\
(800)\end{array}$ & 50 & & \\
\hline 6 & Hughes & $\left(8^{22} 3 / 4\right)$ & JD8 & Open & DM855 & $\begin{array}{c}1075 \\
(3526)\end{array}$ & $\begin{array}{c}19 \\
(62)\end{array}$ & $21 / 2$ & $\begin{array}{c}9 \\
(20)\end{array}$ & 60 & $\begin{array}{c}3500 \\
(500)\end{array}$ & 65 & & \\
\hline 7 & Reed & $\left(8^{22} 3 / 4\right)$ & F34J & Open & 604953 & $\begin{array}{c}1098 \\
(3602)\end{array}$ & $\begin{array}{c}23 \\
(76)\end{array}$ & 6 & $\begin{array}{c}2 / 4 \\
(4 / 8)\end{array}$ & - & $\begin{array}{r}7900 \\
(1150)\end{array}$ & 76 & & Turbodrill \\
\hline 8 & Reed & $\left(8^{22} 3 / 4\right)$ & F31GJ & Open & 837588 & $\begin{array}{c}1174 \\
(3853)\end{array}$ & $\begin{array}{c}77 \\
(251)\end{array}$ & 10 & $\begin{array}{l}2 / 3 \\
(5 / 7)\end{array}$ & - & $\begin{array}{r}6600 \\
(950)\end{array}$ & 62 & & Turbodr111 \\
\hline 9 & Reed & $\left(8^{22} 3 / 4\right)$ & F34J & Open & 604621 & $\begin{array}{c}1229 \\
(4032)\end{array}$ & $\begin{array}{c}55 \\
(179)\end{array}$ & $181 / 2$ & $\begin{array}{l}4 / 8 \\
(4 / 18)\end{array}$ & 60 & $\begin{array}{r}4100 \\
(600)\end{array}$ & 76 & & \\
\hline 10 & Security & $\left(8^{22} 3 / 4\right)$ & M84F & Open & 829016 & $\begin{array}{c}1405 \\
(4608)\end{array}$ & $\begin{array}{c}176 \\
(576)\end{array}$ & 23 & $\begin{array}{c}8 \\
(18)\end{array}$ & 70 & $\begin{array}{r}5500 \\
(800)\end{array}$ & 65 & & \\
\hline 11 & Securlty & $\left(8^{22} 3 / 4\right)$ & M84F & Open & 829066 & $\begin{array}{c}1508 \\
(4947)\end{array}$ & $\begin{array}{c}103 \\
(339)\end{array}$ & 34 & $\begin{array}{c}11 \\
(24)\end{array}$ & 60 & $\begin{array}{r}5500 \\
(800)\end{array}$ & 76 & & \\
\hline 12 & Hughes & $\left(8^{22} 3 / 4\right)$ & ง77 & Open & FL:260 & $\begin{array}{c}1545 \\
(5069)\end{array}$ & $\begin{array}{c}37 \\
(122)\end{array}$ & 22 & $\begin{array}{c}12 \\
(26)\end{array}$ & 60 & $\begin{array}{r}3500 \\
(500)\end{array}$ & 68 & & \\
\hline 13 & Security & $\left(8^{22} 3 / 4\right)$ & $H-100-F$ & Open & 712017 & $\begin{array}{c}1566 \\
(5138)\end{array}$ & $\begin{array}{c}21 \\
(69)\end{array}$ & 19 & $\begin{array}{c}12 \\
(26)\end{array}$ & 65 & $\begin{array}{l}2800 / 5500 \\
(400 / 800)\end{array}$ & 78 & & \\
\hline 14 & Hughes & $\left(8^{22} 3 / 4\right)$ & 377 & Open & FL255 & $\begin{array}{c}1589 \\
(5212)\end{array}$ & $\begin{array}{c}23 \\
(74)\end{array}$ & $201 / 2$ & $\begin{array}{c}7 / 11 \\
(15 / 25)\end{array}$ & 50 & $\begin{array}{l}5500 \\
(800)\end{array}$ & 76 & & \\
\hline 15 & Security & $\left(8^{22} 3 / 4\right)$ & M84F & Open & 815783 & - & - & - & - & - & $\begin{array}{r}6900 \\
(1000)\end{array}$ & 75 & & \\
\hline $16(R R)$ & ) Hughes & $(8.22)$ & J77 & Open & - & $\begin{array}{c}1610 \\
(5283)\end{array}$ & (71) & 19 & $\begin{array}{c}11 \\
(25)\end{array}$ & 60 & $\begin{array}{r}5500 \\
(800)\end{array}$ & 65 & & \\
\hline
\end{tabular}


TABLE B-II (Cont.)

\begin{tabular}{|c|c|c|c|c|c|c|c|c|c|c|c|c|c|c|}
\hline Bits & Make & $\begin{array}{c}\text { Size } \\
{[\mathrm{cm}(i n .)]}\end{array}$ & Type & Jets & $\begin{array}{l}\text { Number } \\
\text { Serial }\end{array}$ & $\begin{array}{c}\text { Dépth } \\
\text { Out } \\
{[\mathrm{m}(\mathrm{ft})]}\end{array}$ & $\begin{array}{c}\text { Total } \\
\text { Footage } \\
{[\mathrm{m}(\mathrm{ft})]}\end{array}$ & Hours & 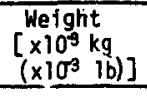 & RPM & 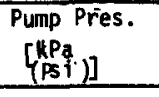 & SPM & $\begin{array}{c}\text { Dull } \\
\text { Condition } \\
T / B / G \\
\end{array}$ & Remarks \\
\hline 17 & Securtty & $\left(8^{22} 3 / 4\right)$ & $H-100-F$ & Open & 774156 & $\begin{array}{c}1654 \\
(5427)\end{array}$ & $\begin{array}{c}46 \\
(151)\end{array}$ & 25 & $\begin{array}{l}11 \\
(25)\end{array}$ & 65 & $\begin{array}{l}6200 \\
(900)\end{array}$ & 65 & & \\
\hline 18 & Hughes & $\left(8^{22} 3 / 4\right)$ & XDV & Open & EN186 & $\begin{array}{c}1104 \\
(3622)\end{array}$ & $\begin{array}{l}20 \\
(67)\end{array}$ & 12 & $\begin{array}{c}1 \\
(2)\end{array}$ & 120 & $\begin{array}{c}6900 \\
(1000)\end{array}$ & 75 & & $\begin{array}{l}\text { Bldg. Shoulder } \\
\text { for } 48\end{array}$ \\
\hline \multicolumn{2}{|c|}{19 (RR)Reed } & $\left(8^{22} 3 / 4\right)$ & - & Open & 604621 & $=$ & - & - & - & - & - & - & & $\begin{array}{l}\text { Bldg. Shoulder } \\
\text { for } 48\end{array}$ \\
\hline 20 & Reed & $\left(8^{22} 3 / 4\right)$ & F34J & Open & 229288 & $\begin{array}{c}1126 \\
(3696)\end{array}$ & $\begin{array}{c}12 \\
(41)\end{array}$ & 10 & $\begin{array}{c}1 \\
(2)\end{array}$ & $=$ & $\begin{array}{c}7900 \\
(1150)\end{array}$ & 72 & & Turbodrill \\
\hline 21 & Reed & $\left(8^{22} 3 / 4\right)$ & F31G & Open & 837584 & $\begin{array}{c}1127 \\
(3697)\end{array}$ & $\stackrel{0}{(1)}$ & $21 / 2$ & $\begin{array}{c}1 \\
(2)\end{array}$ & - & $\begin{array}{c}7900 \\
(1150)\end{array}$ & 72 & & Reaming \\
\hline 22 & Reed & $\left(8^{22} 3 / 4\right)$ & F31G & Open & 837583 & $\begin{array}{c}1222 \\
(4009)\end{array}$ & $\begin{array}{c}95 \\
(312)\end{array}$ & 10 & (6) & - & $\begin{array}{c}8300 \\
(1200)\end{array}$ & 72 & & Turbodr111 \\
\hline 23 & Security & $\left(8^{22} 3 / 4\right)$ & 588 & Open & 711010 & $\begin{array}{c}1414 \\
(4640)\end{array}$ & $\begin{array}{c}192 \\
(631)\end{array}$ & 31 & $\begin{array}{c}3 \\
(6)\end{array}$ & 70 & $\begin{array}{l}4800 / 5500 \\
(700 / 800)\end{array}$ & 70 & & \\
\hline 24 & Hycalog & $\left(7^{20} 7 / 8\right)$ & CMHIP & - & 17479 & $\begin{array}{l}7419 \\
(4656)\end{array}$ & $\begin{array}{c}5 \\
(16)\end{array}$ & 2 & $\begin{array}{c}8 \\
(18)\end{array}$ & 75 & $\begin{array}{l}1700 \\
(250)\end{array}$ & 24 & & Coring \\
\hline 25 & Hycalog & $\left(7^{20} 7 / 8\right)$ & PC2OP & - & 17184 & $\begin{array}{c}1424 \\
(4671)\end{array}$ & $\begin{array}{c}5 \\
(15)\end{array}$ & 1 & $\begin{array}{c}8 \\
(18)\end{array}$ & 80 & $\begin{array}{l}1200 \\
(175)\end{array}$ & 22 & & Coring \\
\hline 26 & Hughes & $\left(8^{22} 3 / 4\right)$ & ง77 & Open & $F 1214$ & $\begin{array}{c}1473 \\
(4833)\end{array}$ & $\begin{array}{c}50 \\
(163)\end{array}$ & $201 / 2$ & $\begin{array}{c}10 \\
(23)\end{array}$ & 55 & $\begin{array}{l}4100 \\
(600)\end{array}$ & 70 & & \\
\hline 27 & Hughes & $\left(8^{22} 3 / 4\right)$ & 377 & Open & FL257 & $\begin{array}{c}1503 \\
(4930)\end{array}$ & $\begin{array}{c}30 \\
(97)\end{array}$ & $221 / 2$ & $\begin{array}{c}10 \\
(23)\end{array}$ & 55 & $\begin{array}{l}4100 \\
(600)\end{array}$ & 70 & & \\
\hline 28 & Security & $\left(8^{22} 3 / 4\right)$ & $H-100-F$ & Open & 697630 & $\begin{array}{c}1541 \\
(5056)\end{array}$ & $\begin{array}{c}38 \\
(126)\end{array}$ & 25 & $\begin{array}{c}10 \\
(23)\end{array}$ & 58 & $\begin{array}{l}2800 \\
(400)\end{array}$ & 72 & & \\
\hline 29 & Security & $\left(8^{22} 3 / 4\right)$ & $H-100-F$ & Open & 680202 & $\begin{array}{c}1559 \\
(5115)\end{array}$ & $\begin{array}{c}18 \\
(59)\end{array}$ & $161 / 2$ & $\begin{array}{c}10 \\
(23)\end{array}$ & 56 & $\begin{array}{l}4100 \\
(600)\end{array}$ & $72^{\circ}$ & & \\
\hline
\end{tabular}




\section{APPENDIX C}

\section{DIRECTIONAL DRILLING SURVEY SUMMARY}

The following tables and figure contain excerpts from the Eastman Whipstock Multiple-Shot Survey records for both legs of well RRGP -4 . 


\section{TABLE C-I}

DIRECTIONAL DRILLING SURVEY SUMMARY, RRGP-4A

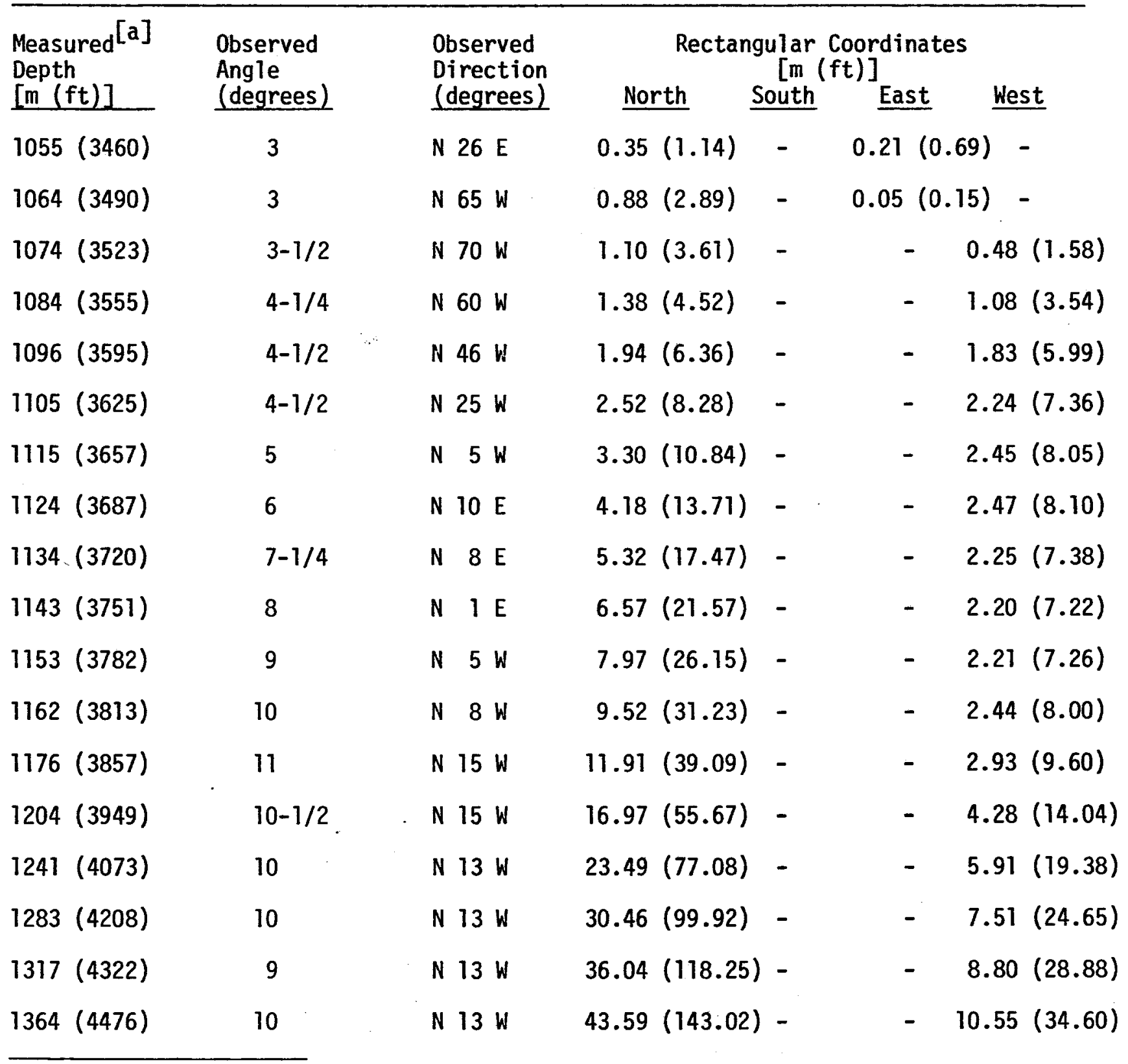

[a] The leg is assumed to be vertical from a depth of 0 to $1055 \mathrm{~m}(0$ to $3460 \mathrm{ft}$ ). 


\section{Table C-I (Cont.)}

\begin{tabular}{|c|c|c|c|c|c|}
\hline \multirow{2}{*}{$\begin{array}{l}\text { Measured }[\mathrm{a}] \\
\text { Depth } \\
{[\mathrm{m}(\mathrm{ft})]}\end{array}$} & \multirow{2}{*}{$\begin{array}{l}\text { Observed } \\
\text { Angle } \\
\text { (degrees) }\end{array}$} & \multirow{2}{*}{$\begin{array}{l}\text { Observed } \\
\text { Direction } \\
\text { (degrees) }\end{array}$} & \multicolumn{3}{|c|}{$\begin{array}{c}\text { Rectangular Coordinates } \\
{[\mathrm{m}(\mathrm{ft})]}\end{array}$} \\
\hline & & & North & East & West \\
\hline $1412(4632)$ & $9-1 / 2$ & $\mathrm{~N} 12 \mathrm{~W}$ & $51.45(168.81)-$ & - & $12.29(40.32)$ \\
\hline $1440(4726)$ & 10 & N $10 \mathrm{~W}$ & $56.22(184.44)-$ & - & $13.22(43.36)$ \\
\hline $1497(4913)$ & 10 & N $11 \mathrm{~W}$ & $65.95(216.37)-$ & - & $15.02(49.28)$ \\
\hline $1575(5167)$ & 12 & N $10 \mathrm{~W}$ & $80.47(264.02)-$ & - & 17.71 (58.11) \\
\hline
\end{tabular}

[a] The leg is assumed to be vertical from a depth of 0 to $1055 \mathrm{~m}(0$ to $3460 \mathrm{ft})$. 


\section{TABLE C-II}

DIRECTIONAL DRILLING SURVEY SUMMARY, RRGP-4B

\begin{tabular}{|c|c|c|c|c|c|c|}
\hline \multirow{2}{*}{$\begin{array}{l}\text { Measured }[a] \\
\text { Depth } \\
{[m(f t)]}\end{array}$} & \multirow{2}{*}{$\begin{array}{l}\text { Observed } \\
\text { Angle } \\
\text { (degrees) }\end{array}$} & \multirow{2}{*}{$\begin{array}{l}\text { Observed } \\
\text { Direction } \\
\text { (degrees) } \\
\end{array}$} & \multicolumn{4}{|c|}{$\begin{array}{c}\text { Rectangular Coordinates } \\
{[\mathrm{m}(\mathrm{ft})]}\end{array}$} \\
\hline & & & North & ith & East & West \\
\hline $1055(3460)$ & 3 & N $26 E$ & $0.43(1.41)$ & - & $0.21 \quad(0.69$ & ) - \\
\hline $1064(3490)$ & 3 & N $65 \mathrm{~W}$ & $0.88(2.89)$ & - & $0.05(0.15$ & i) - \\
\hline $1084(3555)$ & $4-1 / 4$ & N $60 \mathrm{~W}$ & $1.46(4.79)$ & - & - & $1.04(3.40)$ \\
\hline $1092(3582)$ & 4 & $N 58 W$ & $1.76(5.79)$ & - & - & $1.54(5.06)$ \\
\hline $1098(3603)$ & 4 & N $35 \mathrm{~W}$ & $2.26(7.41)$ & - & - & $1.98(6.49)$ \\
\hline (3646) & $4-1 / 2$ & N $37 \mathrm{~W}$ & $2.86(9.39)$ & - & - & $2.42(7.93)$ \\
\hline 1121 (3677) & 4 & N $19 \mathrm{~W}$ & $3.48(11.42)$ & - & - & $2.75(9.01)$ \\
\hline $1130(3706)$ & 4 & $N \perp E$ & $4.09(13.42)$ & - & - & $2.84(9.33)$ \\
\hline 1138 (3735) & 4 & N $20 \mathrm{E}$ & $4.70(15.41)$ & - & - & $2.74(8.98)$ \\
\hline 1147 (3764) & $3-1 / 4$ & $N 70 E$ & $5.86(19.24)$ & - & - & $1.34(4.41)$ \\
\hline 1174 (3853) & $6-1 / 4$ & N $65 \mathrm{E}$ & $6.21 \quad(20.37)$ & - & - & $0.52(1.69)$ \\
\hline 1193 (3913) & $8-3 / 4$ & N $63 \mathrm{E}$ & $7.25(23.80)$ & - & $1.63(5.35$ & 5) - \\
\hline 1211 (3973) & 11 & $N 70 \mathrm{E}$ & $8.50(2790)$ & - & $4.51(14.7$ & 9) - \\
\hline $1262(4142)$ & 11 & $N 71 E$ & $11.30(37.06)$ & - & $13.93(45.7$ & 1) - \\
\hline $1328(4356)$ & 11 & $N 82 E$ & $13.56(44.50)$ & - & $26.17(85.8$ & 36) - \\
\hline $1404(4605)$ & $10-1 / 4$ & $N 80 E$ & $15.75(51.68)$ & - & 39.99 (131. & 21)- \\
\hline $1441(4728)$ & $10-1 / 2$ & N $82 E$ & $16.81(55.15)$ & - & 46.66 (153. & 08)- \\
\hline $1460(4790)$ & $10-1 / 2$ & N $80 E$ & $17.35(56.92)$ & - & $50.06(164$. & 24)- \\
\hline $1535(5036)$ & 14 & N $70 \mathrm{E}$ & $2150(70.54)$ & - & 65.55 (215. & 07)- \\
\hline
\end{tabular}

[a] The leg is assumed to be vertical from a depth of 0 to $1055 \mathrm{~m}(0$ to $3460 \mathrm{ft})$. 


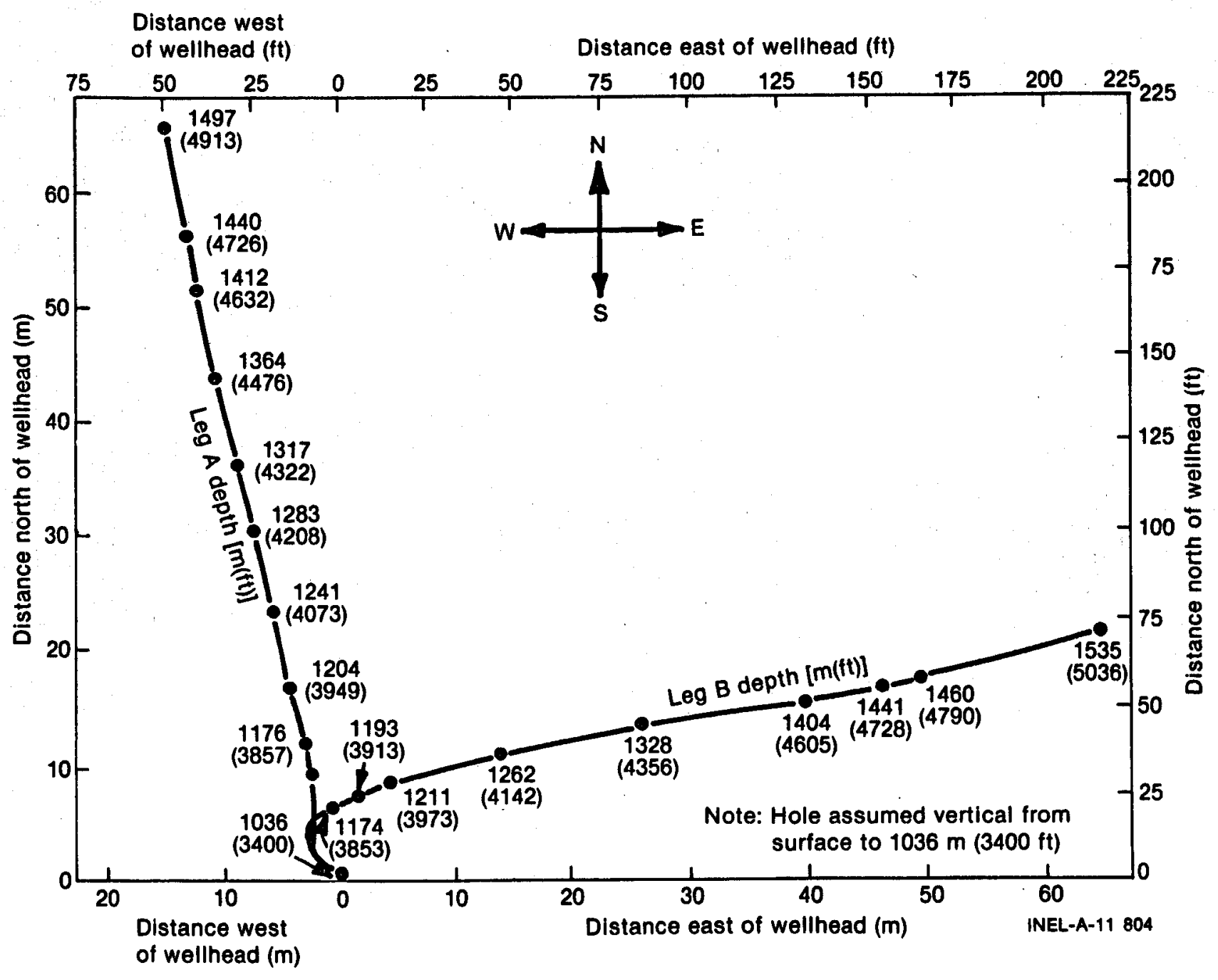

Fig. C-1 Directional drilling survey summary. 
APPENDIX D

\section{CASING SUMMARY}

The following tables contain excerpts from notes recorded in the drilling superintendent's casing record notebook. 
TABLE D-I

INTERMEDIATE CASING SUMMARY

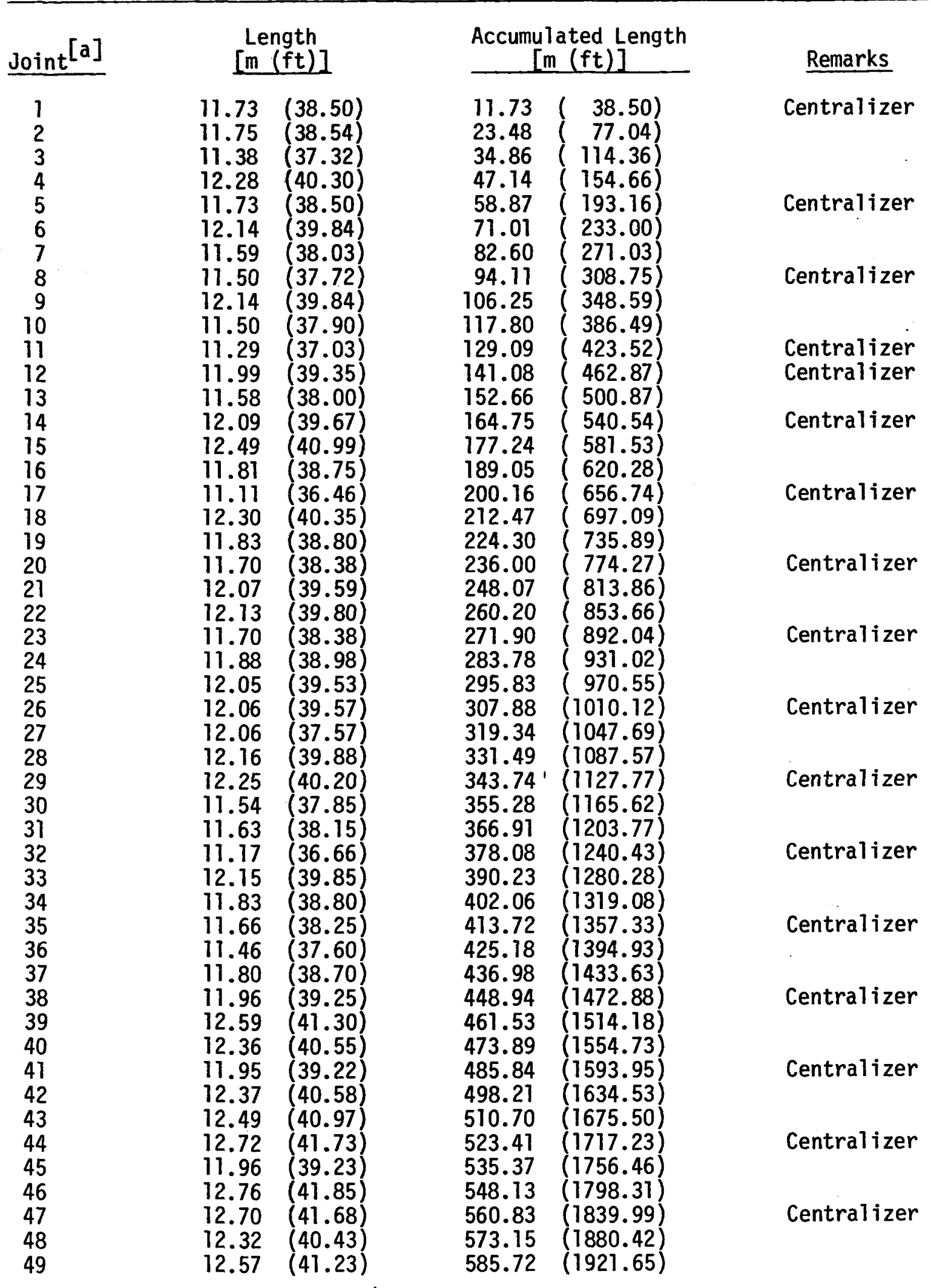

[a]A11 casing was $34 \mathrm{~cm}(13-3 / 8 \mathrm{in.}), \mathrm{K}-55, \mathrm{ST \& C}, 81 \mathrm{~kg} / \mathrm{m}(54.5 \mathrm{lb} / \mathrm{ft})$, Range-3. 
TABLE D-II

PRODUCTION CASING SUMMARY

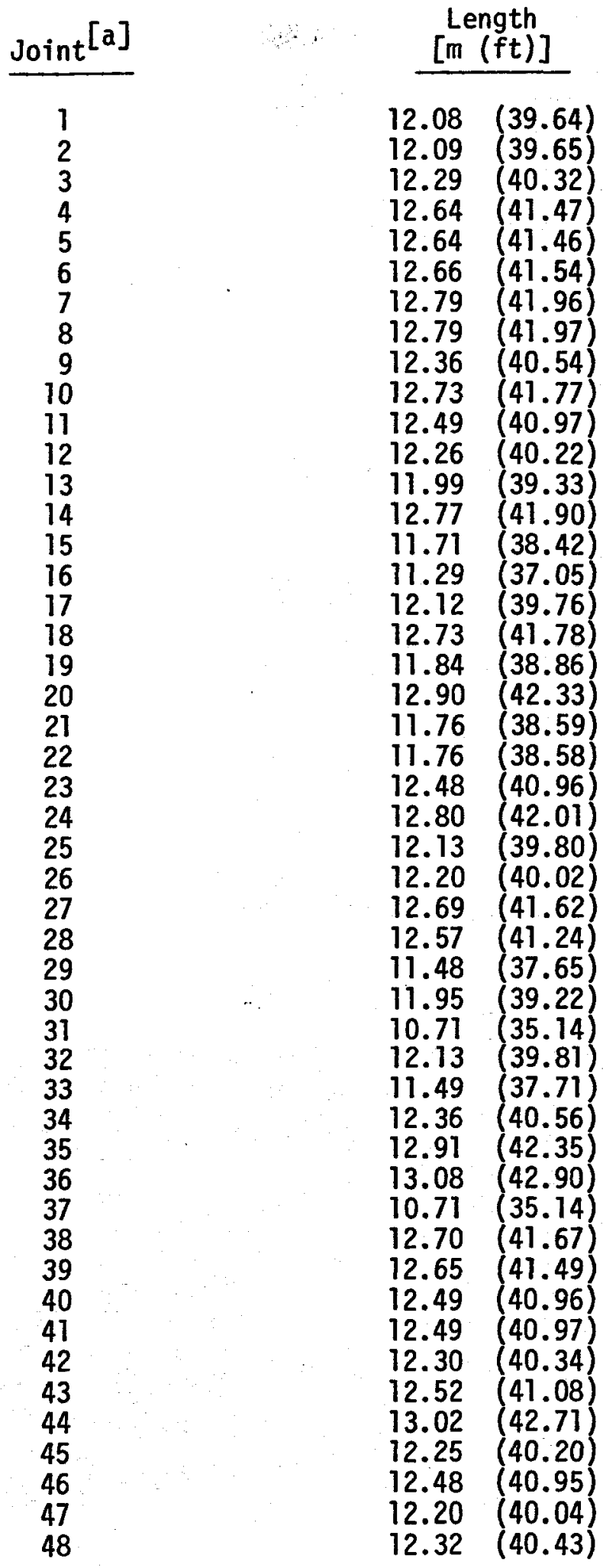

Accumulated Length $[\mathrm{m}(\mathrm{ft})]$

$\begin{array}{ll}12.08 & \left(\begin{array}{r}39.64) \\ 24.17\end{array}\right. \\ 36.46 & (19.29) \\ 49.10 & (19.61) \\ 61.73 & (161.08) \\ 74.40 & (244.54) \\ 87.18 & (286.04) \\ 99.98 & (328.01) \\ 112.33 & (368.55) \\ 125.07 & (410.32) \\ 137.55 & (451.29) \\ 149.81 & (491.51) \\ 161.80 & (530.84) \\ 174.57 & (572.74) \\ 186.28 & (611.16) \\ 197.57 & (648.21) \\ 209.69 & (687.97) \\ 222.43 & (729.75) \\ 234.27 & (768.61) \\ 247.17 & (810.94) \\ 258.94 & (849.53) \\ 270.70 & (888.11) \\ 283.18 & (929.07) \\ 295.99 & (971.08) \\ 308.12 & (1010.88) \\ 320.31 & (1050.90) \\ 333.00 & (1092.52) \\ 345.57 & (1133.76) \\ 357.05 & (1171.41) \\ 369.00 & (1210.63) \\ 379.71 & (1245.77) \\ 391.84 & (1285.58) \\ 403.34 & (1323.29) \\ 417.23 & (1368.85) \\ 428.61 & (1406.20) \\ 441.69 & (1449.10) \\ 452.40 & (1484.24) \\ 465.10 & (1525.91) \\ 477.74 & (1567.40) \\ 490.23 & (1608.36) \\ 502.72 & (1649.33) \\ 515.01 & (1689.67) \\ 527.53 & (1730.75) \\ 540.55 & (1773.46) \\ 552.80 & (1813.66) \\ 565.29 & (1854.61) \\ 577.49 & (1894.65) \\ 589.81 & (1935.08)\end{array}$

$[a]_{A 11}$ casing was $24 \mathrm{~cm}(9-5 / 8$ in. $), k-55$, Buttress Thread, $54 \mathrm{~kg} / \mathrm{m}(361 \mathrm{~b} / \mathrm{ft})$, Range-3. 
DISTRIBUTION RECORD FOR IDO-10081

\title{
Internal Distribution
}

\author{
1 - Chicago Patent Group - DOE \\ 9800 South Cass \\ Argonne, IL 60439 \\ 1 - R. L. Blackledge \\ Idaho Operations Office - DOE \\ Idaho Fa11s, ID 83401 \\ 1 - H. P. Pearson \\ Information Processing - EG\&G \\ 6 - INEL Technical Library \\ 200 - Special Internal
}

External Distribution

393 - UC-66c - GE--Drilling Technology

Total Copies Printed: 602 